\title{
Edirne Valisi Ahmed İzzet Paşa Divançesi
}

\section{Ali YÖRÜR'}

\begin{abstract}
APA: Yörür, A. (2019). Edirne Valisi Ahmed İzzet Paşa Divançesi. RumeliDE Dil ve Edebiyat Araşttrmaları Dergisi, (16), 409-427. DOI: 10.29000/rumelide.618979
\end{abstract}

\section{$\ddot{O} \mathbf{z}$}

Klasik Türk edebiyatı çalışmalarında metin neşri önemli bir yer tutmaktadır. Klasik edebiyatın en önemli eserlerinden olan divanların önemli bir kısmının tenkitli metni yapılmış, yayımlanmıştır. Ancak divançelerden halen yeni yazıya aktarılmamış olanlar vardır. Klasik Türk edebiyatının güzelliklerini, inceliklerini ve döneminin özelliklerini tespit edebilmek için bütün metinlerin çeviri yazımlarının yapılması gerekmektedir. Çalışmamıza konu olan eser, Edirne Valisi Ahmed İzzet Paşa Divançesi'dir. Divançe'nin bilinen tek nüshası Edirne Selimiye Yazma Eser Kütüphanesi 22 Sel 2311 numarada kayıtlıdır. Bu makalede bugüne kadar hakkında çalışma bulunmayan Ahmed İzzet Paşa'nın hayatı üzerinde durulmuş, Edirneli Ahmed Bâdî Efendi tarafından istinsah edilen divançenin transkripsiyonlu metni verilmiştir.

Anahtar kelimeler: Edirne, Ahmed İzzet Paşa, Divançe.

\section{The Divançe of Ahmed İzzet Pasha The Governor of Edirne}

\begin{abstract}
The publication of texts occupies an important place in studies on Classical Turkish Literature. The critical texts of a significant part of Divan poetries which are one of the most important works of Classical literature were produced and published. However, there remain Divançe [a small collection of poems] texts that have yet to be transcribed into the Latin script. Thus, in order to determine the aesthetics and elegances of Classical Turkish literature and the features of the period, it is required to make a transcription of all texts. The Divançe of Ahmed İzzet Pasha, the Governor of Edirne is the subject of the present study. The sole known copy of the Divançe is registered with archive number 22 Sel 2311 at the Edirne Selimiye Manuscript Library. This paper highlights the life of Ahmed İzet Pasha, for whom no other study has been conducted to date and then provides a transcribed text of the Divançe that was copied by Ahmed Bâdî Efendi of Edirne.
\end{abstract}

Keywords: Edirne, Ahmed İzzet Pasha, Divançe.

\section{Edirne Valisi Ahmed İzzet Paşa}

Ahmed İzzet Paşa, Girit Valisi Erzincanlı Hacı Osman Haşim Paşa’nın oğludur. H.1213/M.1798/99'da Erzincan'da doğdu. ${ }^{2}$ Babasının H.1240/M.1824'te vefatı üzerine İstanbul'a geldi. Bir müddet İstanbul'da kaldıktan sonra Erzincan'a gitmiştir. H.1256/M.1840'da Çıldır kazası kaymakamlığına ve H.1257/M.1841'de Anadolu Ordusu Erkan Meclisi azalığına tayin edilmiştir. 15 Cemâziyelâhir H.1265'de (M. Mayıs 1849) vezir unvanıyla Hakkâri ve Van valisi olarak görev yapmış ve H.1266/M.185o'de bu

1 Öğr. Gör., Kastamonu Üniversitesi, Rektörlük Türk Dili Bölümü (Kastamonu, Türkiye), ali.yorur@hotmail.com, ORCID ID: 0000-0003-1434-2995 [Makale kaylt tarihi: 17.05.2019-kabul tarihi:20.09.2019; DOI: 10.2900o/rumelide.580571] Fatin Tezkiresinde H.1229/M.1812'de ve Son Asır Türk Şairlerinde H.1228/M.1813’te Resmo(Girit)'da doğduğu ifade edilmektedir. 
görevinden ayrılmıştır. H.1267/1850 ve H.1268/M.1268'de Cidde valisi olup H.1270/M.1854 yllında bu görevinden ayrılmıştır. H.1271/M.1855'te Kürdistan valisi olup H.1273/M.1856'da ayrılmış, H.1275/M.1858'de Trablus valisi olup H.1277/M.1860'da da bu görevinden ayrılmıştır. H.1278/M.1861'de Muhacirin Komisyonu reisi olup Harput ve Sivas valiliği görevlerinde bulunmuştur. H.1884/M.1301'de Kadri Paşa'nın vefatı üzerine Edirne valiliğine tayin olunmuştur. Birinci rütbe Mecidî, murassa Osmanî nişanlarını, altın ve gümüş madalyalarını almıştır. Namık Paşa'dan "Şeyhü'lvüzerâ" ünvanı kendisine intikal etmiştir. Bir hafta kadar hasta olarak yattıktan sonra H.1310/M.1893'de vefat etmiştir. Edirne'de Üç şerefeli Camii'nin arkasında Peykler medresesi ile Saatli Medrese'nin arasındaki türbeye defnedilmiştir (Peremeci 2011: 162; İnal 1988: c.II,756; Ahmed Bâdî 2014: c. II/I, 1082; Özkan 2015: 469).

Edirneli Ahmed Bâdî Efendi onun ölümüne şu tarihçeyi yazmıştır:

Vâlî-i Edrine düstûr-ı mükerrem ya'ni

Hacı Osman Paşazâde Hacı İzzet Paşa

Nâmı Ahmed idi ol zât-ı celîlü'l-kadrün

Mazhar-1 lutf-1 Muhammed ola der-rûz-1 cezâ

Yaş döküp iki gözünden didi Bâdî târih

Göçti Firdevs-i 'alâya Hacı İzzet Paşa (Ahmed Bâdî 2014: c. II/I, 1083).

Ahmed İzzet Paşa, servet sahibi, tedbirli, güçlü bir kişiliğe sahiptir. 1877/78 Osmanlı-Rus savaşında servetinin 10.000 lirasını orduya vermiştir. Kendinden kırk sene önce vefat eden oğlu Hürrem Paşa'nın adının yaşatılması için Erzincan'da büyük bir cami yaptırmış ve hayratlar yapmıştır (Süreyya 1996: 844). Ahmed İzzet Paşa aynı zamanda yazmış olduğu şiir ve gazelleri ile iyi bir şairdir.

\section{Edirne Valisi Ahmed İzzet Paşa Divançesi}

Ahmed İzzet Paşa'nın Divançe'si Edirne Selimiye Yazma Eser Kütüphanesi'nde 22 Sel 2311 arşiv numarasında kayıtlıdır. Şimdilik yazmanın tek nüshası vardır. Divançe, 26 varaktan ibarettir ve Edirneli Ahmed Bâdî Efendi tarafından istinsah edilmiştir.

Tevhid manzumesinin bulunmadı̆̆ divançe miraciye ile başlamaktadır. Daha sonra na't ve tazarru manzumeleri bulunmaktadır. Ardından sadrazam Reşîd Paşa için bir kaside mevcuttur. Sonra imtiyaz için bir teşekkür-nâme ve terci-i bend vardır. Bundan sonra Nâbî ve Hâmî-i Âmidî’nin gazellerine tahmisler vardır. Sonra na’t ve tazarru manzumeleri bulunmaktadır.

Daha sonra Gazeliyyât başlı̆̆ı bulunmaktadır. Bu bölümde 22 gazel vardır. Gazellerden sonra karışık beyit, kita ve matla manzumeleri mevcuttur.

Divançe'nin sonunda Tevârîh başlıklı kısım vardır. Bu bölümde rütbe tarihi, yeni yıl tebrikleri, Sivastopol'ün fethi, Rumeli demiryolunun açılışı, Edirne piyade kışlasının tamiri, Edirne Sarayı tamiri, II. Abdülhamid'in tahta çııışı, Safvet Paşa'nın sadrazam olması, Sait Paşa'nın sadrazam olması, Belediye hastanesinin tamiri, Edirne'de piyade kışlası camiinin yapımı, Saraçhane Köprüsü’nün yenilenmesi, Edirne Kâdirî Tekkesi'nin yenilenmesi, Sezâyî Dergâhı'nın tamiri, Tırnovacık Camii’nin yapımı, piyade kışlasının batı tarafına hastane yapılması, Topkapı dışında Hakkı Paşa Camii’nin yapımı, Çoban Ali 
Efendi Dergâhı'nın tamiri, Saçlı İbrahim Efendi Tekkesi'nin yenilenmesi hakkında tarih manzumeleri bulunmaktadır3.

Ahmed İzzet Paşa Divançesi’ndeki şiirlerin muhtevasına bakıldığında büyük bir kısmının münâcât ve na’t tarzında yazılmış gazeller olduğu görülmektedir Ayrıca kaside nazım biçimi ile yazılan miraciye4 de bulunmaktadır. Son bölümdeki tarih manzumeleri, döneminin sosyo-kültürel olaylarını göstermesi bakımından önemlidir.

\section{DīVĀNÇE}

$\mathbf{1 b}$

\section{Mi'rāciye-i Hażret-i Nebevī}

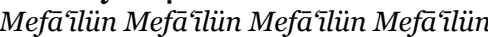

1. Hudā bir sebde mi'rāca habībin eyledi isrā

O şebde oldı zāhir sırr-ı sübhānelleži esrāā

2. Resūlulāh olup ‘āzim-i harīm beyt-i a'zamdan Sa‘ādet ile evvel menzil oldı Mescid-i akṣāa

3. Olup rākib Burāḳ’a șahratullāh-ı müşerrefden Teveccüh-kerde-i ikbāli oldı ‘ālem-i bālā

4. Melā'ik șaflarından oldı șā'id șöyle kim 'arşa Kevākib arasından geçdi gūyā mihr-i nūr-efzā

5. 'Urūc itdi hudūd-ı sidreye Cibrīl olup ḳā’id Vülūc itdi ‘ale'l-ālāya refref oldu reh-peymā

6. Bıraḳdı Refrefi de 'unsuriyetden olup 'ārì Sarāy-ı lā-mekāna vāṣıl oldı vāhịid ü tenhā

7. İrișdi öyle ricāle o med'uvv-i mu'az̧zam kim Ne kemm ü keyf ü ne cānib ü șūret ḳaldı ne ma'nā

8. Mübārek çeşm-i cismi ile gördi vech-i Ma'būdı Tekellüm oldı vākıı' anda beyne'l-'abdi ve'l-Mevlā

9. Ne kim ma'rūż u mefrūż oldı 'ayn-i luṭf u raḥmetdir Bütün Hakḳ’tan 'ināyetdir lehu'l-cūd ve lehu'n-na'mā

10. İdüp eflāk ü 'arş ü kürsi seyr-i avd-i Ahmedle Yine rū-yı zemīne oldı ol şebde şeref-bahşā

11. Zamān içre zamān halḳ eyleyüp țayy-i mekān eyler Zamānile mekānı halk iden Hallāk-ı bì-hemtā

12. Bu hālet çok degildir kudret-i Bārīye nisbetle Kim oldur 'ālemi ketm-i 'ademden eyleyen peydā

13. Zihī șāni‘ ki feyżāà-yı celālinden zemīn zerre Degil beydā-1 'izzinde semā bir ḩayme-i haḍāā

14. Ne gördi ne haber virdiyse 'İzzet seyyid-i ‘ālem

Yörür, Ali (2019), “Edirne Valisi Ahmed İzzet Paşa’nın Tarih Manzumeleri” Littera Turca Journal Turkish Language and Literature Yll: 5 Sayı: 3.

4 Yörür, Ali (2018), “Edirne Valisi Ahmed İzzet Paşa’nın Mi’râciye’si” MECMUA Uluslararası Sosyal Bilimler Dergisi Yıl:3 Sayl: 6.

İsrā/ 1. "Bir gece, kendisine bazı ayetlerimizi gösterelim diye kulunu Mescid-i Haram'dan çevresini mübarek kıldığımız Mescid-i Aksā'ya götüren Allah eksikliklerden münezzehtir. O, gerçekten işitendir, görendir"

$2 \quad$ Levlāke levlāk, lemmā halaktü’l-eflāk hadīs-i kudsīsinden iktibastır. "Sen olmasaydın, sen olmasaydın (yā Muhammed) yeri göğü yaratmazdım" Onun ruhuna sonsuz selam, esenlik olsun / Ya Rabbi, esenliği yarını olmayan yarınlara kadar sürsün.
15. H Hițāb-ı pāk-ı levlāke anı ḳılmışdı maẓhar Haḳk Meyān-ı mā’ u tīne konmamıșken Ādem ü Havvā İāhī tā be-ān ferdā ki u rā nist bes ferdā $\bar{a}^{3}$

7. Habīb-i Rabb-i ‘izzetdir şeh-i taht-ı nübüvvetdir Vücūdı halḳa rahmetdir şefi‘-i rūz-ı rūz-ı vāveylā

18. Temessük eyle şer‘ ü sünnete olma Haḳk’tan gāâfil Degildir kimseye bākī seni aldatmasun dünyā

19. O sultān-ı serīr-ārāy-ı dīvān-ı risālet kim Cihād va'di ile kıldı cihāna hükmini icrā

20. Gelüp geçdi selefden nīce şāhān-ı cihān-gīrān Kim itdi șafha-i ‘ālemde böyle nāmını ibḳā

21. Anıñ hạaḳk oldığın işbāta kāfìdir bu keyfiyet Egerçi eylemișdir mu'cizātı ‘ālemi imlā

Na't-1 Serif

Mefāinlün Mefāīlün Mefāīlün Mefāîlün

1. Eyā şāhinşeh-i iḳlīm-i sübhānellez̄i esrā

Veyā fermān-revā-yı hıtța-i 'ulyā-yı mā evhā

2. Hủıdīv-i enbiyā șāḥib-i serīr ḳurb-i ev ednā Ḥabīb-i ḥażret-i Mevlā şefi‘-i rūz-ı vāveylā

3. Münevver eylemişdi ‘ālem-i lāhūtı envārı̃ Şu demler kim bu ‘ālemler idi nā-būd u nā-peydā

4. Huțāb-ı rahmeten li’l-‘ālemīn eyledi maẓhar Hudā zāàt-ı şerīfiñ ey rasūl-i merḥamet-peydā

5. Bütün bāy u gedā seyyān ola dīvān-ı kübrāda 'Ușāt-ı ümmete sensin penāh u melce' ü me’vā

6. Şefi`u’l-müznibīnsin bir siyeh-rū bendeyim bende Beni ālūde dāmān itdi çirk-i ma‘șıyet hayfā
16. Tahıyyāt u selām-ı bì-nihāye ber-revāneş bād 
7. Garīke-i baḥr-ı 'ișyānım ḥarīke-i nār-ı țugyāāım 2b Vücūhile perīşānım zelīl ü mücrim ü rüsvā

8. Şefā'at eyle hevl-i rūz-ı rüstā-hīzden kurtar Beni zīr-i livā’ül-ḥamde ḳ̂l luṭuñ ile esrā

9. Eli bağlu esīr-i dūzah itme yā Rasūlallāh Ne deñlü mücrim ise ümmetiñdir 'İzzet-i şeydā

\section{Na't-1 Şerï}

Fāilātün Fã'ilātün Fãíilātün Fāíilün

1. Yā Muhammed var idiñ sen yogiken 'ālem henüz Gelmemişdi sāḥa-i īcāda pīş ü kem henüz

2. Eylemişdi ümmetiñ ḥaḳḳında Ḥaḳk va'd-i necāt Itmeden ḳavm-i Neciyullāhı gark-ı yüm henüz

3. Virmiș idiñ zīb ü fer nūr-ı risāletle temām On sekiz biñ ‘āleme halḳ olmadan Ādem henüz

4. Zāhir idi ümmet-i merhūme sende hürmeti Konmamışken bezm-i 'ayn-ı nūşa cằm-ı Cem henüz

5. Maḥrem-i ḩalvet-serā-yı ḳudsī idiñ ey pādişāh Olmamıșdı ol harīme kimseler mahrem henüz

6. 'İzzet'i eyle halās ey rahmeten li'l-‘ālemīn İtmeden ḳaddin herās rūz-ı mahş̧er ḩam henüz

\section{Na't-1 Şerï}

1. Nār-1 rusul-i fahr-ı cihān

2. Mahbūb-ı Rabb-i müste‘̄ān

3. Șāḥib-i serīr-i lā-mekān

4. Peyġamber-i āḩir zemān

5. Ey server-i her dū-serā

6. Fahr-1 rusul-i hayru'l-verā

7. Șāhib-i serīr-i isțtıā

8. Maḥbūb-ı Rabb-i müste‘ān

9. Sensin şefíu'l-müznnibīn

10. Hem sạadikư'l-va'dü'l-emīn

11. Çün rahmeten li'l-ālemīn

12. Şānıñda bürhān 'ayān

13. Sensin emīn ü șādık

14. Oldı kamer emriñle şakk

15. Kuldı seni Rabbü'l-felak

16. Mihr-i semā-yı 'izz ü şān

3a

17. Nutkuñ degil nutk-ı hevā

18. Her bir sözüñ vahy-i Hudā

19. Emriñe vācib iktidā

20. Şer 'iñ mețā'-1 ins ü cān

21. Dergāhıña her șubḥ u şām

22. 'İzzet kavliñ bā-ihtirām

23. 'Arż-ı tahı̣yyetle müdām

24. İtmekde tezyīn lisān

25. Netdimse ben itdim baña

26. Oldum giriftār-ı hevā

27. Kublem nice cürm ü hațāa

28. Kim idemem żikr ü beyān

29. Ey rehber-i rāh-ı hüdā

30. Kıldım saña rūhum fedā

31. Yoḳ bende bundan mā-'adā
32. Taḳdīme lāyık armaġan

33. Oldum esīr-i nefs-i bed

34. İtdim hatâa-yı lā-yu'add

35. Gafletde kaldım el-meded

36. Kendi elimden el-emān

\section{Nazm}

Mefāîiün Mefāîlün Fe ūlün

1. Göründi çeşmime şehr-i Medīne Yine Elhamdülillāhi Te‘̂āā

2. Nice şehr-i şeref-peydā kim anı Savb-ı halḳ eylemiş Huallāḳ-ı dānā

3. Didi hicret idince fahr-1 'ālem Eyā dānende-i serrā vü ḍarrā

4. Esirdiñ Mekke'den luṭuña Bārī Beni ḳıl sevdigiñ bir şehre isrā

5. Anunçün oldı istihsān-ı Hakk' la Medīne pādişāh-ı dīne me'vā

6. Nice fahr itmesün rū-yı zemīne Ki sākin anda şāh-ı tah̆t-ı esrā

7. Maḳām-ı pāk-i fahr-ı mürselīni Merci' ḳldı 'arş u kürse Mevlā

8. Müşābih mi olur hīç bir diyāra Cināna beñzer ol şehr-i dilārā

9. Kim olmus mevki'i hayru'l-mevki Hevāsı rūḥ-bahş pīr ü bernā

3b

10. Ki her bir şāḩ bir rūḥ-ı muṣavver Semārı mīve-i Firdevs-i a lā

11. Lisān-ı hālile enhārı eyler Rumūz-ı tahtehā'l-enhārı īmā

12. Yā vașf-ı mescid-i seyyid-i risālet Ne mümkindir ola ta'rīf ü ìmā

13. Meyān-ı minber ḳabr-i sa‘ādet Muhakkak ravża-i cennāt-ı a'lā

Tażarru'

Fāílātün Fā'ilātün Fāîlün

1. Ben ne kelbim yā ìlāhe'l-ālemīn

K'eyleyem dergāhıña vaż'-ı cebīn

2 Sen baña kıldıñ müyesser yā kerīm Sensin ol hallāḳ-ı zü̈'l-feyżü'l-'amīm

3. TTâ̄iffi beyne'l-harām itdiñ beni Zā’ir-i fahru'l-enām itdiñ beni

4. Senden ayru yok baña yā Rabb ìlāh Ümmet-i Ahmed'denim bī-iștibāh

5. Yüz sürüp ihlāsile yā Rabbenā Beytiñi ḳldım penāh u mültecā

\section{Ve-lehū}

Mefāilün Mefāịiün Mefâîlün Mefāîün

1. Cehennem nārı korısın ki yansun yā Rasūlallāh Bu cismi kim aniñla zikriñi itmekdeyim her ān 
2. Ben ol bir mücrimim ki eylemezse şefkatiñ imdād İder feryād u efḡānım zemīn-i mahşseri lerzān

3. Olurdı yeryüzi mānend-i deryā bu nedāmetle Eger olsa sirişkim çeşm-i huūn-efşāndan rīzān

4. Şefā'atle beni ḳıl maẓhar-ı 'afv-ı İlāhī kim Zebānīler elinde olmayam şermende vü giryān

5. Gönül tevhīd-i Hakḳ taṣdīḳ-i zāātñndan degil gāail Bu cān tevhīid-i Ḥaḳḳ tașdīḳ-i zaāt-i pākiñe ḳurbān

$4 a$

Kașīde-i Der-Sitāyiş-i Ṣadr-ı A'ẓam Reşīd Paşa Fāíilātün Fã'ilātün Fã'ilātün Fā'ilün

$1 \quad$ Hażret-i sadr-i celīlü’l-kadr sāmīi i'tibār Àṣaf-ı sānī medār-ı iftiȟār-ı rūzigār

2. Vāriș-i Hārūn u reşk-i Hārūnu'r-Reşīd Bermekī cūd u Niẓāmü’l-mülk Risto iştihār

3. S Sadr-ı mülk-ārā Reşīd Paşa-yı ‘āliş̧ān kim Olamaz dergāh-ı iclālinde Dārā yerde dār

4. Ebbedallāhü te‘ālā şānehü iclālehü Ebbedallāhü be-iḳbāli ilā yevmi'l-ḳarār

5. Eyledi ikmāl-i nāmūs-ı celīl-i salțanat İtdirüp bir devlete tarżiye vü hem i'tizāar

6. Misli mesbūḳ olmadık hıdmetler itdi itdi devlete ‘Avn-i Ḥaḳk’la ol vezīr-i bì-nazị̄r-i kām-kār

7. Āṣafü'l-'ahd felek-cāh u mu'allā cāy-gāh Ḥămil-i mihr-i şehinşāh Süleymān-ı ị̣tidār

8. Ol semmī șāhib-i mihr-i nübüvet kim olur Her ümūrunda mu'īn ü yāveri perverdigār

9. Revnak-efzā-yı șadāret āb-ı rū-yı salțanat Mesned-ārā-yı vekālet dāver-i ‘ālī-tebār

10. Șadr-i maḥmūdü's-seyr destūr-ı İskender eser Bende-perver merhamet-güster Hูıdīv-i nām-dār

11. Dest-gīr-i derdmendān ü zahīr-i bī-kesān Mültecā-yı dād-ȟª̄hān Āṣaf-ı şefkat-și‘ār

12. Mihr-i gerdūn-ı celālet-kim kemāl-i luṭifile Zìr ü bālāyı müsāvāt üzre eyler tāb-dār

13. İktibās-ı nūr ider envār-ı 'adlinden cihān Feyż-i luṭfundan olur 'âlem serāser vāye-dār

14. Sū-be-sū eylerdi kesb-i lezzetet 'azbü̈'l-Fürāt Ger nesīm-i feyż itse rūy-ı deryādan güzāā

15. Luțfile ḳılsa naẓar dünyāyı eyler gülistān Kahrile baḳsa eger gülzārı eyler ḩākisār

$4 \mathbf{b}$

16. Desti rīş-i reşk-i ḥayretde ḳalurdı tā-ebed Remz fikrin fehme Eflāțūn olaydı 'uhde-dār

17. Def'-i żarr u celb-i nef'-i mülk ü milletdir 'arż Her ne kim re’y eylese ol ‘Āṣaf-ı gayret-medār

18. O yer yer asayiş itdi 'ālemi tedbīri kim İdemez oldı gazālāne esed renc ü hasāār
19. Görse İskender eger 'așr-ı mehāsin ḥıșrını Reşkile vādī-i zulmetde iderdi āh u zār

20. Hey’et-i hạaliye-i ‘ālemden istiḩrāc ider Șūret-i keyfiyet-i müstaḳbeli ol fehm-kār

21. 'Ālemiñ böyle refāh ḥālini eslāfda Var ise görmüş işitmiş söylesün Allāh var

22. Böyle ser-gerdān olup devri der miydi felek Zerreler miḳdārı temkīninden olsa behre-dār

23. K Kılsa iḳtidārın murād ol Âṣaf-ı 'āli-himem Hem-per-i sīmurg olur bir peşe-i bī-iḳtidār

24. Bāl ü per açsun firāz-1 çerḩa yer var eylesün Āsitānı üzre bir kere ḳonan mürg̀-i nizār

25. Hamdülillāh eyledim ol āsitānı intisāb Bende oldum bende-gān-ı bāb-ı luṭfundan şümār

26. Çok zamānlardır ki olmuşdum kemāl-i şevkịile Dāmen-i iḥsānnña yüz sürmege ümīd-vār

27. Vāṣıl-ı sermenzil-i makșūd olup fevḳa'l-emel Ol șerefle kām-yāb oldum be-luțf-ı gerd-kār

28. Kullugì ile mübāhāt itdigim devlet yeter Ber-ḥayāt oldukca kāfidir baña iftiḩār

29. H Hāk-i pāy-i luṭ̣ına yüz sürdigim günden berü Ṣığmaz oldı ‘aleme kesb itdigim fahr u mesār

30. Var iken dilde neşāṭ-ı iltifăt-ı devleti Virseler biñ cām u Cem itmem kabūl u i'tibār

31. Biñde bir şükri olmaz yine bu ni'metiñ Eylesem rūz u mesā ḥıṣr-ı hayāt-ı müste‘ār

32. Fahreyle ol zaāt-ı memdūḥu'ṣ-șıfātıñ vāṣıfı Şevkete da'vā-yı rüchāniyet itse ḥaḳkıı var

$5 \mathbf{a}$

33 Düldül țab‘ıla meydān-ı hüner kerrārıyım Ḩāme-i mu'ciz-beyānımdır elimde züu'l-fikāār

34. Pehlüvān-ı heft-h̆ ${ }^{` a} n$ 'azm-i me‘ānīyim ki ben Zor țab'ım 'arșa-i 'irfānı eyler ra'şe-dār

35. İște bu ḳudretle ‘āciz oldı vașfında ḳalem ‘Ālemiñ bir nokțada vasfin iderken

36. Ġayb ider hayretle deșt-i midhatinde kendüsin Eşheb endīşeme ‘ālem gelürken teng ü țār

37. Vâș̣l olmaz intihā-yı medḥine biñ hayāl Eylese biñ yll sefer mānend-i berḳ-i bī-ḳarār

38. Kande ben ḳande ārā-yı vașf-ı zāat-ı Āṣafi Zerre kābil mi ide ta'rīf mihre ibtidār

39. Bu teșekkürdür degil evsāf-ı ‘ālīsin beyān Kim anıñ evșāfıdır bir baḥr-ı bī-ḳa'r u kenār

40. Gülşen vașfinda bari bir gazel țarh eyleyüp 'Andelīb-i ḩāme dem-sāz ola mānend-i hezār 
41. Sīb-i hạmrā mı gül-i ra'nā mı yā ruhsāâr-ı yār Yohssa bāgè hüsn ü ān içre açılmış lāle-zār

42. Vechini bilmem ne yüzden māha teşbīh itdiler Var mı mehde ebruvān u hāa ü zülf-i müşg-bārdır

43. Bir hațā ile getürmüş semt-i çìge uğrayup Būy-ı zülfin nāfeye bahş eylemiş bād-ı bahār

44. Olmasun göñlüm gibi pejmürde ey bād-ı șabā Degme luṭf it kākül-i dil-dār olursa reh-güzāār

45. Dil-i zaḩm-dār nigeh-i serdir hevā-yı gīsuvān Bu iki sevdā degil midir iden 'uşşāḳı zār

46. Besdir ițnāb-ı süh̆an 'İzzet yeter tașnī'i ser Eyle àgàà-ı du'à iḩlāṣile leyl ü nehār

47. Tā ki devrān eyleye şems ü kamer șubḥ u mesā Zātını kılsun Hudā pīrāye-bahș-ı rūzigār

48. Pādişāh-ı 'ālemi tah̆tında șadrında anı Pāyidār itsün cenāb-ı Ḥaḳk be-cāh-1 çār-ı yār

5b

Nişān-1 İmtiyāz İçün Teșekkürr-nāme

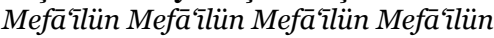

1 Veli’n-ni'met-i bī-minnetim şevketlü hünkārım Yeñi başdan beni itdiñ garīḳ lücce-i iḥsān

2. İdüp ḥaḳk-ı 'abīdānemde luṭfen bende-perverlik Cihān-kıymet 'atạa vü keremle eylediñ şādān

3. Kabūl-i 'atk ü āzād eylemez bir 'abd-i memlūk Kemāl-i raḥmile ḥaḳḳ-ı velāyı eylediñ ityān

4. Bu ihsāna mu'ādil mi olur dünyā vü mā-fì-hā Bu bahşşa hiç muḳābil mi olur maḥṣāul-i baḥr u kān

5. Gice gündüz çalışsam pādişāhım ‘ömrüm oldukç̧a Bu luṭfuñ şükrini îfā degildir kāābil-i imkān

6. Saña ihlāṣile kulluḳdur ancak elde sermāye Yoluñda cāna minnetdir hemān bežl-i metā'-ı cān

7. $\quad$ Şeh-i 'ālem-penāhā pādişāh-ı āsumān-cāhā Seni bir feyże maẓhar eylemiş kim hażret-i Yezdān

8. Konarsa südde-i dergāhıña bir peşe-i kemter Hümā-pervāz olur eyler firāz çerḩa dil-i țayrān

9. Sehinșāhā sen ol sultān-ı 'ālemsin ki ihsānı̃ İder halḳ-ı cihānı cān u dilden bende-i fermān

10. H Hudāvendā sen ol hāḳān-ı a'z̧amsın ki dergāhıñ Penāh-ı ‘ācizāndır būse-gāh-ı zümre-i şāhān

11. Edā-yı şükr-i elțāfiñ beyān-ı hakkḳ-ı evșāfiñ Degil kāl ü kalemle mümkin ey sultạan-ı ‘ālī-șān

12. Hudā müzdād idüp günden güne ‘ömr-i hümāyunuñ Ḳıla tahtıñda bāḳi tā ki devrān eyleye devrān

13. Ola reāyāt-ı ecnādıñ mazhhar düşmeniñ makhūr Bu da'vātı ider vird ü zebān ‘'̇zzet kuluñ her ān

'Atebe-i 'Ulyāya Bi't-taḳdīm Țug̣rā-yı Gazā İle Müzeyyen ü Mülemma' ve Pırlanța İle Murașșa'
Bir Ḳıțta Kưțu İḥsān-1 Hümāyūna Buyurulmuş Olan Terci'-i Bend'dir.

6a

Fāílātün Fāílātün Fāíilātün Fãíilün

1 Hażret-i şāhinşeh-i 'ālem huudāvend-i vahịì Mā-bihi'l-fahr-ı benī Ādem cihān-dār-ı ferīd

2. Mihr-i ‘ālem-tāb-ı gerdūn-ı hilāfet kim anıñ Nūr-1 'adlinden olur āfāk-ı 'ālem müstefìd

3. Ma'diletle mülküni bir rütbe ma'mūr itdi kim Ġıța-gāh-ı rub`'-ı meskūn oldı bir vefḳ-ı ümīd

4. Zirve-i bag̉yaçıkar yol bulmayup encām-ı kār Oldı tagiılır bütün dergāh-ı cūdunda 'abīd

5. Oldı 'ālem sāye-i luțfunda leb-rīz-i sürūr Nāle vü feryāda dā’ir ḳalmadı güft ü şinīd

6. Hamdülillāh zāāim ü maẓlūmı siyān eyledi Devletinde oldı āsāār-ı te'addī nā-bedīd

7. Mazhar-ı feth u zafer fermān-revā-yı bahr u berr Pādişāh-ı dād-güster sāye-i Rabbü'l-mecīd

8. Tāc-dār-ı merhamet-i mu'tād hāan-ı 'Abdü’l-Mecīd Şehriyār-1 şehriyār-ı ecdād 'Abdü’l-Mecīd

1. Dünki gün teşrīf idüp ol pādișāh-ı cem-sipāh Eyledi bāb-ı sipeh-sālārını pür zīb ü şān

2. Öyle gün kim bir demi reșk-āver-i nūr-ı nevrūz u 'īd Öyle gün kim sā‘ati sermāye-i kevn ü mekān

3. 'Asker-i şāhānesin mesrūr u ḩandān eyledi İltifātiyle o sulțān-ı selāțīn-i zamān

4. Eyler elbet leşkeri şükrān 'alā-tilke'n-ni'am İftihārile ugurunda fedā-yı cism ü cānn

5. Bu mübāhāt u meserretle șunūf-ı 'askeri Baș eger mi gelse yüz biñ kere yüz biñ ḳahramān

6. Eylemez hāsşā tenezzül bir nefer İskender'e Kande kaldı sāye-i șāhānesinde żābițān

7. SSāh-ı leşker-perver ü sāhib-kırān-ı kāmūr Pādişāh-ı heft-kişver dāver-gīnī sitān

8. Tāc-dār-ı merhamet-i mu'tād hān-ı 'Abdü'l-Mecīd 6b Şehriyār-1 şehriyār-1 ecdād ‘Abdü’l-Mecīd

III

1. Nūr-ı re'yile münevver şāhid-i mülk-i cihān Būy-ı 'adliyle mu'ațtardır meșāmm-ı salțanat

2. Hüsn-i tedbīrile teshīl oldı kār-ı kāināt Buldı hakkile revāc emr-i mehām-ı salțanat

3. Rahş̧-1 devlet 'arṣa-i nuṣretde cevelān eyledi Tā olaldan destine vāṣıl zimām-ı salțanat

4. Mihr ü meh döndükce țurdukca āsumān Devr ide bezm-i hümāyununda cām-ı salțanat 
5. Kim odur revnak viren gül-zār-ı dīn-i devlete Müftehirdir zāāt-ı pākile maḳām-ı salțanat

6. Müşterī țal'at zühal rif'at mu'allā menzilet Zīb-i bahşs-efser-i 'arş iḥtişām-ı salțanat

7. S Șāhib-i șūr u kerem hnāḳān-ı İskender-i 'alem Bā'is_-i emniyet-ı ‘̄lem niẓām-ı salțanat

8. Tāc-dār-ı merhamet-i mu'tād huān-ı 'Abdü'l-Mecīd Şehriyār-1 şehriyār-ı ecdād ‘Abdü’l-Mecīd

IV

1. Öyle şāhinşāh kim şāhān-ı dehriñ serveri Bende itmez bendegānı dār-ı keyān u kayseri

2. $\quad$ Öyle 'asker öyle ordular müretteb kıldı kim Her biri ḥayret-fezā-yı mevkib-i İskenderi

3. Hāfız-ı 'ālemki tedbīri dilerse hıfz ider Şem'-i sūzānı hevāda mādde hāàk u ahkeri

4. Dāver-i Șıddìk-sīret-kim hemīşe himmeti Harf-be-harf infāz ider ahkām-ı șer'-i enveri

5. 'Ādil-i Fārūke-hilkat-kim nigāh-ı șefkati Gūsfendāne menām eyler künām-ı Ḥaydarı

6. SSāh-1 zü’n-nūreyn-ḩașlet kim kemāl-i 'iffeti Emr-i bi'l-ma'rūf ile icrāda nehy-i münkeri

7. Kahramān-ı murtażā heybetiñe ḳahr u șavleti Ug̉rasa lerzān olur dehşetle çarhıñ çenberi

$7 a$

8. Tāc-dār-ı merhamet-i mu'tād hān-ı 'Abdü'l-Mecīd Şehriyār-ı șehriyār-ı ecdād 'Abdü’l-Mecīd

V

1. Șıdḳile 'İzzet kulı āsā du'ā-yı devletin Rūz u şeb ‘ālem bu minvāl üzere evrād eylesün

2. Gün-be-gün mesrūr idüp Mevlā fu'ād-ı șevketin Düşmen ü bed-ḩ āhını maḳhūr u nāşād eylesün

3. Dem-be-dem olsun serīr-i salțanatda ber-murād 'Āfiyetle ‘ömrini Allāh müzdād eylesün

4. Hụẓ idüp zāt-ı hümāyūnın Hudā ekdārdan Her şebin Ḳadr u șabāḥın șubḥ-ı a'yād eylesün

5. Eyleyüp ecnādını mānend-i encüm-i bī-'aded Hey'et-i cem‘iyyet-i a‘dā-yı berbād eylesün

6. Her țarafdan gālib u manșūr olup orduları Hakk Te‘ālā emrine dünyāyı münḳād eylesün

7. Mülk-i mürüvvetinde ma'mūr olmadık yer kalmadı Ba'd-ezīn alsun diger emlākı ābād eylesün

38. Tầc-dār-ı merhhamet-i mu'tād hhān-ı 'Abdü'l-Mecīd Şehriyār-1 şehriyār-ı ecdād 'Abdü’l-Mecīd

\section{Ġazel-i Nābī Taḩmīs-i Ḥācī 'İzzet Paşa} Mefāîün Mefāîlün Mefāî̀lün Mefāîlün

1. Nişìmen-gāh-ı sulțān-ı serīr-i ıștıfādır bu

2. Makām-ı fahr-ı kevneyn eşref-i her-dū serādır bu

3. Penāh-ı ins ü cāndır mültecā-yı așfiyādır bu

4. Sakıın terk-i edebden kūy-ı mahbūb-ı Hudā'dır bu
5. Naẓar-gāh-ı İlāhīdir maḳām-ı Mușțafầdır bu

6. Bisāt-ı nūr-ı cennetle müzeyyendir hakịikatde

7. Müreccaḥdır ārāżī vü semāvāta şerāfetde

8. Per-i Nāmūs-ı Ekber perdedir ol dār-1 devletde

9. Habīb-i Kibriyānıñ h ȟāb-gāhıdır fażīletde

10. Tefevvuk-kerde-i ‘arș-ı cenāb-ı kibriyādır bu

11. Bu yerde oldı envār-ı nübüvvet 'āleme şāmil

12. Cihān tārīk iken temyīz olundı hakk ile bāṭl

13. Mekān-ı pāk-i sulțān-ı risāletdir ki ve'l-hāạṣl

14. Bu hāāiñ pertevinden oldı deycūr-ı 'adem zā'il

15. 'Amādan açdı mevcūdāt çeșmin tūtiyādır bu

16. Kıyās itme melāik mübtelā-yı infikākıdır

17. Bütün şām u seherer ta'z̧īmile rū-māl-i hāâkidir

18. Ferūg̀-ı nūrınıñ șemsi vü kevākib-i șerm-nākdir

19. Felekde māh-ı nev bābü's-selāmiñ sīne-çākıdır

20. Anıñ ḳandīlidir cevzā mațla'-ı nūr-ı żiyādır bu

21. Dilersen nā'il olmak 'İzzet'ā maksūd u dil-ȟ̄āha

22. Muhabbet eyleme zull-i ḩayāl-i mesned ü cāha

23. Göñülden eyle ihrā́c-ı i tibārı mā-sivāllāha

24. Mürā'āt-ı edeb șartiyle gir Nābī bu dergāha

25. Mețāf-ı kudsiyāndır buse-gāh-ı enbiyādır bu

Ǵazel-i Ḥāmīì Āmidī Tahmīs-i Ḥācī 'İzzet Paşa Mefāîlün Mefāîlün Mefāịlün Mefāīlün

1. Çlḳup taht-ı sipihre hükkm-i 'ālem-gīr ider meh-tāb

2. Sevād-ı leyle 'arş-ı lem'a-i şimşīr ider meh-tāb

3. Süleymāndır ki ḥarș-ı Āmidi tesḩīr ider meh-tāb

4. Cinān resmin Diyār-bekr'de tașvīr ider meh-tāb

5. Kenār-ı Dicle'yi mānend-i cūy-ı şīr ider meh-tāb

6. Bu bezm-i bī-bekāāa ber-ḳarār üzre degil her șey

7. Gehī zevevk ü neşāt īrās_ ider gāhī küdūret mi

8. Tefekkür ile șun'-1 Haḳkıı gafletle hımam tā ki

9. Kemāliñ nakṣı nokṣāniñ kemāli oldığın der-pey

10. Lisān-ı ḥālile kāmillere taḳrīi ider meh-tāb

$8 \mathbf{a}$

11. Diyār-ı hüsn ü ān içre seni itmiş Hुudā yektā

12. Eger haḳḳnñda dinse Yūsuf-ı sāāī sezā hakkāā

13. Saña olmaz mukābil mihr ü māh ‘ālem-i bālā

14. Bilür noksānnñ̃ taklīd-i hüsnüñ idemez tenhā

15. Anıñçün pençe-i huūrşīd ile el bir ider meh-tāb

16. Tecāvüz itme hazm-i ihtiyāț̂ñ iḥtimāsından

17. Degildir cāìz emniyet-i hasūduñ intimāsından

18. Olur ebnā-yı cinsiñ cevri evfer mā-'adāsından

19. Halāṣ olmaz kişi hem-rengüñ āzār u cefāsından

20. Ketāna sā’ir eyşādan füzūn te's_ir ider meh-tāb

21. Semāda basț idüp bir süfre-i șāf dürr-i efşānı

22. Tonatmış meş'al-i 'ālem-fürūz-ı nūr ile anı

23. Kuşatmış hem-çū sāḳi seb`a-i seyyāre her yanı

24. Şükür nuḳl-i nücūma vaż‘ eyle bir māh-ı tābānı

25. Kenār-1 h ȟ ān-ı çarḩa hāleden peş-kīr ider meh-tāb

26. SSeb-i yeldā-yı firḳatden gözi tā ol ḳadar yılmış

27. Ümīd-i șubḥ-ı vașl-1 yārdan gūyā elin silmiş

28. Varup țab-hāne-i hikmetde teftīş-i devā ḳılmış

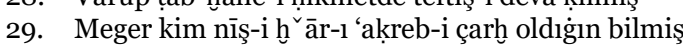

30. Ledìg-i şām-ı hicre şīr ile tedbīr ider meh-tāb

31. Koyup şahne hubūbāt-ı nücūm-ı āsumān üzre

32. Alur mīzănla cev benātü’n-na'şdan behre 
33. Bu 'ādetdir gezer ḳaț'-ı menāzille çıłup devre

34. Hesābın cebr-i nokṣān görmek üzre ayda bir kere

35. Muharrerdir ki aydın kişverin tahrīir ider meh-tāb

36. 'Alīl-i cürmüm ammā var ümīdim Rabb-i 'izzetden

37. Halāṣ eyle beni dārū-yı 'afvile bu 'illetden

38. T Tuyup lā-taknețū āvāzını semt-i hüviyetden

39. Sevād-ı cürm ile kesmem ümīdi nūr-ı rạ̣metden

$8 \mathbf{b}$

40. Hịiāb-ı zulmeti bir laḥẓada tenvīr ider meh-tāb

41. Kimiñ dil-h̆ ${ }^{` a} h ı$ üzre 'İzzetā dünyā müfid oldı

42. Seniñ de țutalım mānend-i Nūh “ömrüñ mezīd olsun

43. Gidüp vaḳt-i cüvānī işte şeybiyet bedīd oldı

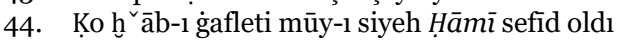

45. Mizāc-ı ítidāl-i nāmını taġyīr ider meh-tāb

\section{Kit'a-i Na'tiye}

1. H Hoş geldiñ eyā nebiyy-i žī-şān

2. Teşrīfiñ ile cihān handān

3. Sensin şeref-i zemīn ü eflāk

4. Hakḳıñnda Hudā buyurdı Levlāk

Fi'l-Mekketi'l-Müşerrefe

Kilīd-i ḳufl-i ümīdim ḳoma destinde mahlūḳuñ İlāhī kendü dest-i ḳudretiñle fetḥ-i bāb eyle

\section{Beyt}

Mefāîiün Mefāîlün Mefāịlün Mefāîlün

İlāhī tīr-i makșūdum ḳarīn-i isticābet ḳıl

Edānī bezmine ta'ẓīm içün ḳadem kemān itme

Beyt

Fāilatün Fã'ilātün Fāílātün Fā'ilün

Görmek isterseñ eger dünyāda rūz-ı mahşeri

Şām’a gel seyr it zuhūr-ı mahmil-i peygamberi

Beyt

Melāz-ı mücrimīndir āsitān-ı āsumān-ı kadriñ

Aña bir bende-i üftāde 'İzzet Yā Rasūlallāh

Beyt

Fāilātün Fã'ilātün Fāílātün Fāíiün

Pādişāhım çok yaşa tahtıñda keyf-i mā-teşă

Dā’imā ol mazhar sırr-ı tu'izzü men teșâ'

$9 \mathbf{a}$

\section{Kit'a}

1. Şeref-bahşā-yı nübüvvet mefhar-i ekvān

2. Habīb-i hażret-i Bārī nebiyy-i bāhiru'l-burhān

3. Sen ol șulțān-ı 'ālemsin şeh-i evlād-1 Âdem'sin

4. Mu'azz̧amsın mükerremsin seniñdir devlet ü dīvān

Beyt

Mefāilün Mefāîlün Mefāîiün Mefāìlün

Mes_eldir küllü strrin cāveze'l-is_neyni şā ${ }^{\circ}$ ey şūh ${ }^{4}$

Amān rāz-ı derūnı açma ag̉yāra nihān ḳalsun

\section{Nazmon Ḥācī ‘'̇zzet Pașa}

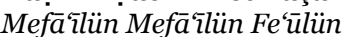

1. Muharremle șafer ba'd-ez rab'īayn

Cemāzeyeyn ü receb şa'bān-ı eşref

2. S S Siyām u 'īd u zị'l-ḳa‘de dehr-i zeyn

Kuned zii'l-hicce 'ālem-rā müşerref

Naẓm-ı Ve-lehū Hācī ‘'̇zzet Paşa

Mefâîlün Mefāî̀ün Mefāîlün Mefāîlün

$4 \quad$ “İki (dudak) yi aşan her sır yayılı”". (Arap Atasözü)
1. Mücāhid ol sebīl-i Haḳk ta gir meydāna merdāne Bu rāhıñ intihāsı ‘izzet-i dāreyne vuṣlatdır

2. Çalış 'askerliginde bende ol 'Abdü'l-Hamīd hāana Ki emrine itạāat hükm-i Kur’ānile müs_betdir

\section{Na_zm-ı Ve-lehū}

Mefāîlün Mefāîiün Mefāîiün Mefāîlün

1. O gözler görmesün kim dergehiñde dīde-bān olmaz O cān çıḳsun ki ‘ịd-i iştiyāḳñnda degil kurbān

2. Gönül 'asskıñla nālāndır gözüm sevkiñle giryāndır Cesed hicriñle sūzāndır bu sūzişle ciger büryāndır

9b

3. Saña ümmetligimdir iftiḩārım yā Rasūlallāh Bu ni'metle nice dünyā vü mā-fỉhā olur seyyān

4. Yüzüm dürdüm mübārek āsitānıñ eyleyüp tels_īm O lezzzetdir dimāğ-ı dilde hạālā eyleyen cevelān

\section{Ve-Lehū Nā-Temām Ġazel}

1. Rüstem-i devrānsıñ şimşīr-i ebrūlarla sen Düssmen-i cānsıñ ḩadeng-i çeşm-i cādūlarla sen

2. Sū-be-sū neşr eyleyüp 'anber-i șemīm-i kākülüñ Tārumār itdiñ dil-i 'uşşāḳı şu būlarla sen

3. Saña eglence yeterken eşk-i çeşm-i ḩasretiñ Sevdigim beyhūde oynarsıñ akarsularla sen

4. İtdi reftārıñ gazālān-ı sebük-cevelānı leng Meșk-i pervāz eylediñ gūyā perestūlarla sen

5. Anda vahşīilik kalur şānıñda s_ābitdir seniñ Da'vī hüsn ü melāḥat itseñ āhūlarla sen

\section{Ve-lehū Nazm}

1. Cenāb-ı ġavs_' 'ulvī şeyh İsmāî̀l Tillovìdir Nesebde cedd-i vālā i'tibārı șeyh̆ Memdūḥ’uñ

2. Ferīdü'l-'așr ekrem șeyh İbrāhīm Hakkıı'dır Mükemmel hู`āce-i himmet-şi‘ārı şeyh Memdūh’un

3. Lisānı fătiḥ-i gencīne-i sırr-ı vülātıdır Kerāmetdir kelām-ı dürr-nis_ārı șeyh̆ Memdūḥ’uñ

4. Kitābı bā ġ-ı 'irfān kendisi tūțīi hoş-elhān Kelāmından olur ma'lūm ‘ayārı şeyh Memdūḥ’uñ

Ve-lehū Nā-temām Na't-i Şerīf

1. Rasūl-i kibriyādır bu

2. Hudiv-i enbiyādır bu

3. Muhammed Muștafāàdır bu

4. Habīb-i hażret-i Mevlā

5. Risālet taḩınıñ şāhı

6. Sa‘ādet burcunuñ māhı

7. Muhammed'dir bu vāllāhi

8. Nebiyy-i lā-mekān-peymā

9. Emīn-i hayay-i Bārīdir

10. Dū-kevne emri cārīdi

11. Şefā'at şeh-süvārıdır

12. Hudāivend-i kerem-fermā

10a 
13. İmāmü'l-mürselīn oldur

14. Emìrü'l-‘ālemīn oldur

15. Penāh-ı 'ācizīn oldur

16. Şefí-i rūz-ı vāveylā

\section{Ve-lehū}

1. Su'leleri virdi iki yüzden feżā-yı ‘āleme Tā beş ruhssārı bir yandan ḳamer bir yandan

2. Kaț içün rāh-ı rakīibi kūy-ı yāre aḳdılar Gözyaşı bir yandan hūn-ı ciger bir yandan

3. İ'tilā-yı ḳudret isterse Hुudā-yı lem-yezel Sevḳ ider tevfik bir yandan kader bir yandan

4. Zevkini bilmem ider gurbetde giryān ādemi Ayrllı̣ bir yandan renc-i sefer bir yandan

\section{Ve-lehū Nazm}

1. Baña șan'atla bir bi’r-i garaż itdiler kim hakk İde kendülerin vākị be-ḥaḳk-ı Aḥmed ü aṣhāb

2. Mu'ānid-i kahrı bir is mi saña yā Rabbi kim sensin İden aṣhāb-ı fili ḩall benī İsrā'îli garkẹ-āb

3. Ma'āzallāh ne efk ü iftirālar itmemişlerdir Vukū'-ı hikmet-i mīlādı fikr it bir alay kezzāāb

4. Bi-ḥamdülillāh açıldı gözlerim bu günleri gördüm Ṭutulmuşdı göñül ālāmla girmezdi çeşme ḩ ${ }^{` a} b$

\section{Ve-lehū}

Fāílātün Fāíllātün Fāílātün Fãíilün

1. Görmedim kūyuñ gibi bir gülșen-i hâațir-güşā Gitdim ey Leylā-‘żārım deşte de hāmūna da

2. Olma maḥzūn ey olan āzürde-i cevr-i enām Bak ne işler itdiler Mūsāya da Hārūn’a da

\section{Ve-lehū Beyt}

Zamān geçmez ki kalsun fitne vü fettāndan hāāī İder her şer tevellüd Mısr'dan çün ümm-i dünyādır

112

\section{Ġazeliyyāt \\ Harfü'l-Elif}

$\mathbf{1}$

Fāilātün Fāíilātün Fāîlātün Fāíiün

1. 'Aş̧ka meyl itdiñ göñül ġamdan ġıdā lāzım saña Terk-i ārām u sükūn en ibtidā lāzım saña

2. Gül'izāāım gülşen-i hüsnüñde feryād itmege Ben gibi bir ‘andelīb-i ḩoş-nevā lāzım saña

3. Kande gitseñ andadır cem 'iyet-i erbāb-ı dil Çünki şāh-ı mülk imişsin iḳtidā lāzım saña

4. Var țayan bir sev-i ḳadde ḩān-ḳāh-ı 'aşḳda Şimdi pīr oldı güzel bir müttekā lāzım saña

5. Ey olan sermest-i șaḥbā-yı gurūr-ı ' 'zz ü cāh Var bu zevḳiñ bir humāāı ittiḳā lāzım saña

6. Ey heves-kār-ı duhūl-ı silk-i așhāb-ı buțūn Evvelen 'ilm ü edeb hịilm ü ḥayā lāzım saña

7. Derd-i 'aşḳ̂ñ var devāsı zann idersen ey țabīb Evvelen terbiyet-i dāru'ş-şifā lāzım saña

8. İş faḳat ü ümrāni-i dünyā ile olmaz temām
Çünki bundan da seferbereyn-i dū-cā lāzım saña

8. Yār-ı deyrini koyup olma riyākārāne yār Dem gelür 'İzzet olur ‘ālem-i būyā lāzım saña

2

$1 \quad$ Sirișk-i çeșm-i terimden șerāb olur peydā Yanında lah̆t-i cigerden kebāb olur peydā

2. Bu çārşūuda güzeldir alış veriş āmmā Tefekkür eyle șoñunda hesesāb olur peydā

3. Kibār-ı devleti mahzụūz ider temelluḳlar Gelince bahs_-i recāya 'itāb olur peydā

4. Temelluḳāta kibār iltifāt ider lākin Gelince mebhas_-i luṭfa 'itāb olur peydā

5. Tag̉ayyurāt-1 şü'ūnāt-ı dehrden 'İzzet Yazılsa gördigimiz bir kitāb olur peydā

11b

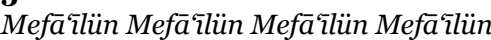

1. Șafā bezminde bir șūh-ı cefā mu'tād olur peydā Anıñçün firḳa-i 'uşşāḳda feryād olur peydā

2. Şü'ūnāt-ı cihān dā’im degildir ber-karār üzre Görürsüñ günde biñ nā-șād u biñ dil-şād olur peydā

3. Tagallüb eyleseñ de hașma mağrūr olma 'ālemde E‘ālìye edānīden daḩī ażdād olur peydā

4. Degil țag̉lar başında dahī emniyetde bir maḩlūk Çerāgāh-ı gazālān içre de șayyād olur peydā

5. Hudā nevmīd-i elțāf eylemez bir 'abd-i melhūfı Ümīd oldur ki Mānī'den Behiye üstād olur peydā

6. Zamān-ı 'adl ü dād hażret-i ‘Abdü'l-Hamīd hāndır Anıñ 'ahdinde 'İzzet șanma kim bīdād olur peydā

1. Gehī bezm içre ol şūh vefā mu'tād olur peydā Nitekim bāg̣da bir serv-i ser-āzād olur peydā

2. $\quad$ Olursun hayr-h ${ }^{\vee} \bar{a} h$ ebnā-yı cinse hüsn-i sīretle Seniñçün haşre deñlü bir şerefli ad olur peydā

3. S_ebāt it istikāmetde baḳılmaz ța'n-ı ag̉yāra Mücerrebdir ki her żī-ni'mete hụssād olur peydā

4. Kazanmış gerçi nāmını anlar ammā deșt-i 'aşk içre Zamān geçmez ki biñ Şīīn ü biñ Ferhād olur peydā

5. Biri dārü'l-cināna digeri gül-zāra mā’ildir Hezār u zāàdan da gerçi kim feryād olur peydā

\section{Harfü'r-Rā}

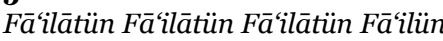

1. Şol ki hengām-ı tevāżu'da mis_āl-i hāa olur Rif'at-i kadri anıñ da hemser-i eflāk olur

2. Būdı Ḥaḳk nābūd ider bir lahżada nābūdı būd Șanma dil būd u ne-būd-ı dehrden ġam-nāk olur

$12 a$

3 Yāda geldikce ruhuñ ca'lī degil şeydālıgìm İhtiyār elden gider ceyb-i tahammül çāk olur 
4. Revze-i hicrān-ı yār eyler ta‘āḳub şöyle kim Olmadan ahşām vuṣlat-ı mevsim-i imsāk olur

5. Nāmdārān olmaz 'İzzet ța'n-ı a'dādan emīn Baḳ nigīne şerḥa-dār-ı gāv sen ḥakkāk olur

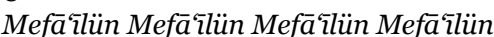

1. Żiyā-endāz olan șahnn-ı cihāna nūr-ı hüsnüñdür Bütün şems ü ḳamer çarh-ı felek mecbūr-ı hüsnüñoür

2. Siyeh kākülleriñ zulmet diyārından gelüp gūyā Dökülmüş gerden üzre ferve-i semmūr-ı hüsnüñdür

3. İki țug̉rā-yı garrādır çekilmiş şekl-i ebrūda Yazılmış ḩāme-i ḳudretle hatț menşūr-ı hüsnüñdür

4. $\quad$ Dil-i gam-h̆ ${ }^{` a}$ ara hicriñle ‘aceb mi olsa șad-pāre Şikest olmaz mı ol āyīne kim mehcūr-ı hüsnüñdür

5. Düşüp meyhāne-i 'aşḳıñda 'İzzet kaldı ser-gerdān Mey-i vașlıñla imdād eyle kim maḩmūr-ı hüsnüñdür

7

1. Șanma derdim devāya kāaibildir Āh serdim semāya vāṣıldır

2. Āteş-i iftirāḳ-ı beyt-i Hudā Sū-be-sū cism ü cāna şāmildir

3. Ben idersem rakīb-i bed-bīne Baña töhmet mi def'-i hā̄'ildir

4. Ben fer-i serān-ı milket-i 'aşḳam Kays u Vāmı ̣ bu yolda rācildir

5. Bā-firākẹ-ı harīm-i fahr-ı rusül Sūziş-endāz-1 hāāne-i dildir

8

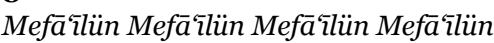

1. Gözümde nem gönüülde āteş-i endūh-ı hasret var Derūnumda mis_āl-i lāle dāğ-ı hecr ü firḳat var

12b

2. Nice murg்-1 göñül semt-i Ḥicāz'a itmesün pervāz Kim ol gülşende tahts-ı şāh-ı iḳlīm-i risālet var

3. Yanar dil iştiyāḳ-ı ravża-i pāk-i habībiñle Hudāvendā bu hicrāna ne kudret var ne țākat var

4. Arandıḳda 'ibād-ı dergehiñ vaḳt-i şefā'atde Disünler defter-i ümmetde bir bīçāre 'İzzet var

\section{Harfü'l-Lām}

9

1. 'Āșlk-ı serdir hevā bir nāy bir ben bir göñül Derd-mend-i bī-nevā bir nāy bir ben bir gönül

2. Nag̉me-sāz dem-be-dem şeb-i zinde-dār u bī-ḳarār Sine-i pür-dāg ṣafā bir nāy bir ben bir gönüül

3. Yaralar açmış derdin dilde ḳanlar ağlamış Hecr-i yārda mübtelā bir nāy bir ben bir göñül

4. Böyle efğān eyleyen kumru mı ya țūṭi midir Bülbül-i şeydā mı yā bir nāy bir ben bir gönüul
5. Rāz-1 'aşḳı diñlemiş 'İzzet gibi āh eylemiş Olmuş aṣlından cüdā bir nāy bir ben bir gönüul

\section{Ḥarfü'l-Mīm}

10

Fāilātün Fāílātün Fāî́ātün Fāîlün

1. Başladıkca cūşa 'aşk-ı kalb-i nālānım benim Bașdırır deryāyı eşk-i çeşm-i giryānım benim

2. S Subḥa sürmez şu'le-i ḳandīl-i māhı neylerim Tāb-ı sūz-ı sīnedir şem'-i şebistānım benim

3. Öyle bir dil-dāra dil dil-dādedir kim dildedir Cān içinde gizlüdür cān gibi cānānım benim

4. 'Āşı ı̣ım ben 'aşıḳa mümkin mi ketm-i rāz-ı 'aşk Rāy-gāndır 'āleme her rāz-ı pinhānım benim

5. Naķş-bendi-i ḥubb-i Mevlāyım bi-ḥaḳḳ-ı ism-i hū Hālidīdir ‘'̇zzetā elkāb-ı ‘ünvānım benim

$13 \mathbf{a}$ 11 Mefāîilün Mefāîilün Mefāîlün Féūlün

1. Leyāl-i gamda baña yār olan göñülcegizim Benimle her gice bīdār olan gönülcegizim

2. T Tarar mı zülfini yāriñ mis_āl-i şāne 'aceb Esīr-i țurre-i țarrār olan göñülcegizim

3. Şikāyet eylemesün kendi itdi kendine Belā-yı hecre giriftār olan göñülcegizim

4. Derūnum eyledi ma'mūr kendin itdi ḩarāb Binā-yı 'aşḳa Sinimmār olan göñülcegizim

5. T Tutuldı dām-ı ferīb-i cihāna murg̀-āsā Ṣafā-yı bāl ile țayyār olan gönüulcegizim

6. Șabāha dek tọolaşur kūy-ı dilberi ‘'̇zzet Benimle her gice bīdār olan gönülcegizim

12

1. Hevā-yı nefse uyup meyl-i 'izz ü cāh itdim Bu hevā-yı dehr ile evkāāimi tebāh itdim

2. Açık iken baña ebvāb-ı luțfi-ı Rabbānī Der-i 'ibāda varup terk-i terk-i șāh-rāh itdim

3. İlāhī 'avniñi rehber ḳlup yolum țog̉rult Ki ben garābetle terk-i şāh-rāh itdim

4. Tagayyurāt-ı şu'ūnı görüp bilen 'âḳil Hudūs_-ı 'āleme hiç dir mi iștibāh itdim

5. Ziyānı sūdını degmez bu sūk-i fānīniñ 'Abes_cerāyid-i a'mālimi siyāh itdim

6. Bütün nümāyişi vehm ü hayāldir 'İzzet Dū-çeşm-i 'ibret ile ‘āleme nigāh itdim

\section{Harfü'n-Nūn}

13

Fãilātün Fāîlātün Fāílātün Fāílātün

1. Gösterince tābiş-i hüsnüñ o Yūsuf-ı pīrehen Oldılar üftāde-gān engüşt-i hayret-i ber-dehen

2. Bezme 'azm itdikde mānend-i tīz-rev hoş-ḩirām Maḳdemiyle cennet-i a lāya döndi encümen 
13b

3. Ol ḳadd-i mümtāza oldum sāde ben mi mübtelā 'Āşı oldı ḳāmet ü reftārına serv ü çemen

4. Pertev-endāz-ı cemāl olduḳda șaḥn-ı gülşene Reşkle orak atdı derd-i nesrīn ü semen

5. $\quad$ Olmadı meh münkesif döndürdi şerminden yüzin 'Arż idince tal'at-ı ruhsārını ol sīm-ten

6. Sevdigim gül-zār-ı kūyuñdan ba 'īd olsun raḳīb Lāyı olmaz kim ide ülfet melekle Ehrimen

7. Naẓar-1 şīinnimde var te's_īr-i iksīr-i hayāt Olmaz ‘'̇zzet böyle lezzzet bahşs-ı ‘ālem her suhan

8. Sūd-mend olmak dilersen kıl tevekkülde s_ebāt Ekl ider şūrbāyı dirler ḩānkāhı bekleyen

9. Ma'nī-i men-lem yežlu ve lem ya'rifís der-pīş idüp Virme kand-i ma‘rifet nādān-i erzen-h̆ª̄a sen

10. Rāhat olmaz cāyigāhı olsa da bāg̀-ı İrem Bir garīibiñ kim țutar ḳalbinde yer ḥubbü'l-vațan

11. İtme şeyțānlık saña emniyyet iden ādama Kāle fahru'l-kā'ināt el-müsteşāru mü'temen ${ }^{6}$

12. İtdigin bulmaz mı ẓann eyler ihānet pīşe-ger Der-i każādır intiḳāma seyf-i Rabb-i zü̉'l-minen

14

Mefāîlün Mefāîlün Mefāịlün Mefãîlün

1. Gönül bir dilberiñ 'aşkıyla sūzān gösterir kendin Şeb-i tārīk-i hasretde fürūzān gösterir kendin

2. Beyān-ı hāàle furșat bulmadım ol şūh̆h ıì-raḥme ‘Ayān-1 ítibār-1 yāre pinhān gösterir kendin

3. Yanar mı 'aşḳ̂ñla āteşlere pervāne-veş bülbül Faḳaț şāhn-ı gül üzre zār u giryān gösterir kendin

4. Şecā'at-i lāfla olmaz șakın aldanma 'ādetdir Cebīnü'l-ḩulk olanlar merd-i meydān gösterir kendin

5. Baḳarsañ dīde-i 'ibretle ger mir'āt-i gerdūna Fenā-yı șūret-i ‘ālem-nümāyān gösterir kendin

6. Tevessül ḳll Rasūlallāha țut zeyl-i 'azīzānı Bu meslekde olan dünyāya sulțān gösterir kendin

$14 a$

7. Ne mahviyyetdedir gör āsitān-ı pīr-i Geylānī Ki her mūr-1 ża'îfi bir Süleymān gösterir kendin

8. Görülmüş mi 'aceb 'İzzet gibi bir merd-i rūşen-dil Mükedderken gam-ı 'ālemle handān gösterir kendin

\section{Harfü'l-Hā'}

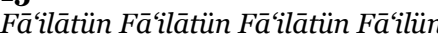

1. $\quad$ Eyle merhem bu dil-i bīmāra Allāh 'aşkııı

Oldı zaḩm-ı hecrile biñ yara Allāh 'aşḳına

2. Olmasun göñlüm gibi pejmurde ey bād-ı șabā Degme luțf it kākül-i dildāra Allāh 'așkına "Tatmayan bilemez. Kim ki tatmamış; o, tadını bilemez".
3. Sen getür bari peyām-ı yāri ey peyk-i hayāā Bag̉ludur āmed-şod neẓzāāra Allāh 'aşḳına

4. Dāhil-i dāru'ș-şifā-yı vuṣlat it bendeñi Düşmesün Mecnūn-veş kūh-sāra Allāh 'aşḳına

5. Āḳııet ifşā-yı rāz-ı 'aşḳ iderler el-emān Açma sırrın sevdigim aġyāra Allāh 'aşḳıına

6. Derd-i hecriñle ser-i kūyuñda bir üftādedir Merḥamet ḳıl ‘'̇zzet-i ġam-ḩ`āra Allāh ‘aşḳına

16

Fāílātün Fāíilātün Fã'ilātün Fãíilün

1. Beytü'l-ahzān gam-ı dehr olmuşiken dā’irem İltifātın ḳıldı hem-tā cennetü'l-me'vā ile

2. Ey ḩıdīv-i cem-i himem bir gūne şād itdiñ beni Kim degildir vașfi mümkin 'arż ile inhā ile

3. S Sem‘-i bahtım şöyle iş‘āl eylediñ kim āṣafā Olsa hem-ser çok mı huūrşīd-i felek-pervā ile

4. Lāne-gīr-i gülșen-i 'aşḳıñ olahıdan murg̀-i di Var mı farḳım baḳ nevā-yı bülbül-i şeydā ile

5. Haşre dek kilk ü zebān cān u dil kūyundadır Vașf-ı pāk-ı hażret-i sadr-ı kerem-pīā ile

6. Āsitānıñda uçan kemter mekesler faḩr idüp Vaṣf-ı pervāz-ı hümāyı diñler istihzā ile

$14 b$

7. Hāṣılātından olan mı böyle olmaz neş'e-dār İtseler de tā ki isḳā bāğda ṣahbā ile

17

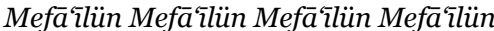

1. Yine meyl itdi dil bir şūhn-ı āhū-çeşm-i mey-nūşa Bu sevdā ile geldi bahr-ı şevk-i ārzū cūșa

2. Vuṣūl-i menzil-i makssūda bežl-i naḳd olur bā'is Yanaşmaz olmadıḳca sīm ü zerr dilberde āğūşa

3. Sühnan ismā'ına bir gūş-1 șāhịib-i hūş lāzımdır Dür-i şehvarı menkūs itmek olmaz gūş ḩar-gūşa

4. Kiyāfet ile makbūl-i enām olmaz ferd-i māye Muṣayḳal olsa da tamġa urulmaz sīm maģşūşe

5. Olur pāymāl-i zillet 'āḳibet mest-i mey-i nahvet Mes_eldir bu ki kendüsi yıkılur degme ser-ḩūşa

6. Görünce heybet-i șir ü pelengi fāre olur hirre İder ammā ki şīāna tasalluṭ kendüsi mūşa

7. Hümūm 'uzleti degmez server-i manșıb-ı dünyā Hુumārın dikmeyen șahbā gerekmez rind-i bā-hūşa

8. Hükūmet hamlini ‘'̇zzet tahammül emr-i müşkildir Odur 'ākil ki bu bār-ı kerānı almaya dūşa

\section{Harfü'l-Yā' \\ 18 \\ Fã'ilātün Fāílātün Fāílātün Fā'ilün}

6 "Fikrine başvurulacak olan kimse(müsteşār), itimad edilen kimse olmalıdır". (Hadis-i Şerif) 
1. Eşk-i çeşmim menba'-1 'ummānı giryān eyledi Nār-ı 'aşḳım ḥūt-i taḥte'l-arżı büryān eyledi

2. Nāle-i şeb-gāhım 'arş u ferşe șaldı velvele Dūd-ı āhım dūdımān-ı çerḩi sūzān eyledi

3. Bir țarafdan fikr-i gurbet bir țarafdan hecr-i yār Hูāne-i kạalb-i ḥazīnim beytü’l-aḥzān eyledi

4. Tìg-i tīz-ebruvānı yara açdı sīnede Ġamze-i hūn-rīzi remy-i nevk-i müjgān eyledi

5. Gerden-i billūruñ üzre serpilüp gīsūlarıñ Sāha-i hü̈snüñ ser-ā-pā sünbülistān eyledi

6. Āşinālık itmediñ bir kere bu gam-ȟ ${ }^{2}$ āreye Bunca yıllardır ser-i kūyuñda efḡān eyledi

$15 \mathbf{a}$

7. Ḥaḳk dilerse ḥıfz ider düşmenle düşmenden seni Gūsfende nitekim kelbi nigeh-bān eyledi

8. 'Usrı seyr eyler te‘ākub eyleme kaț'-ı ümīd Böyledir ahvāl-i 'ālem böyle devrān eyledi

9. Eylesün sūḳ-ı ma‘āifde münādāiler nidā Nev-ḳumaş naẓmı 'İzzet zīb-i dükkān eyledi

19 Mefāîüün Mefāîlün Fe ūlün

1. Bu meclisde mey ü sāḳi kạalur mı Şu āheng ü țarab bāḳi ḳalur m

2. Felek serkeşlik eyler şimdi ammā Anıñ da necm ü āfāḳı kalur mı

3. Tefekkür eyle ey sermest-i ikbāl Bu sükkeriñ saña ezvvāḳı ḳalur mı

4. Hazān-ālūd olur her bāìg u büstān Gül ezhār u evrāḳı kạlur mı

5. Haț-āver olıcak bir şūh-ı gül-ruh Anıñ 'uşşāḳ u müştāḳı ḳalur mı

Fāilātün Fāilātün Fāiilün

1. Țurre-i țarrārıñ ol perçem dahi Hâț̣̂rı zār itdiler dirhem dahi

2. İktifā itmek ne mümkin görmege Ṭymam ol ruhsārdan ölsem dahi

3. Ag̈ladıkca artdı bahr-ı firkatim Kalmadı gözümde artı̣̣ nem dahi

4. Züll ile olsa eger āb-1 ḥayāt İ̀tikāb itmem anı ölsem daḩi

5. Olmadıkca bahtı Țāhā'nın mu'ayyen Aña ‘'́tzzet neylesün ādem dahi

$$
21
$$

1. Çeşmim yaşı kim şarāba döndi Laḩt-ı cigerim kebāba döndi

15b

2. Tārāc ideli sipāh-ı hecriñ Dil taht-gehī harāba döndi

3. Kūyuñda geçen huceste demler
Bi’l-cümle hayāal-i ḩ`āba döndi

4. S Sīr-āb-ı zülāldir kūh-ken Deryā-yı emel serāba döndi

5. Bāb-ı keremiñ penāh-ı 'ālem 'İzzet bu yüzini o bāba döndi

22 Fāilātün Fāilātün Fāílātün Fāiilün

1. Bulmasun 'ālemde furșat hod-nümālardan biri Görmesün mir’āt-ı devlet bed-likālardan biri

2. Aldanup ikbāline meyl itmez insāniyyetle Ṭutalım ki ehl-i cāh olmuş gedālardan biri

3. 'Āşıı̣ıñ feryādına ḳılmaz nigāh-ı iltifāt Bu degil mi işte vaż́-ı nā-sezālardan biri

4. Yār olur bīgāne-gāna ol büt-i nā-mihribān Kūyına gitse ider redd āşinālardan biri

5. Hecrile kaldım yanar ag̉lar bu vādīlerde ben İtmedi şefkat baḳup da dil-rübālardan biri

6. Kimseyi dū nān içün dūnāna muhtāc eyleme Bār-gāhiñdan budur yā Rabb ricālardan biri

7. Bezm-gāh-ı ‘ālemiñ incāz u encāmın bilüp Mest-i gaflet olmaz 'İzzet zī-nehālardan biri

$17 \mathbf{a}$

\section{Nazm}

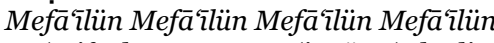

1. Ma'ārif ādeme sermāye 'izz ü sa'ādetdir Teraḳkīi hüner 'imrānī-i aḳvāma âletdir

2. İder sa'y u 'ameli insān mālik feyż-ı dāreyne Bu feyże nā’iliyyetden iden maḥrūm 'ațāletdir

3. Olur hâaṣıl-ı kavvām dīn ü dünyā 'ilm ü șan'atla ‘ìlimdir dīni ma'mūr eyleyen mülki șa'nātdır

\section{Kit'a}

1. Kemān-ebrūlarıñ ḳavs-i każadır

2. Siyeh kākülleriñ başa beladır

3. Ne şübhe șayd ider 'ankāāı çeşmiñ

4. O müjgānlar ki tīr-i ber-hevādır

\section{Ve-lehū}

1. Götür bu nazmımı tāk-ı nigāristāna ta līk it

2. Yoluñ ug̉rarsa ey băd-1 șabā ger Çin ü Māçīn'e

3. Cevāb-ı redle me'yūs eyleme ümīd-dārānı

4. İder erbāb-1 hạācet 'arż-ı hạāl elbet selātīne

\section{Ve-lehū}

1. Ne esbāba teşebbüs_den ne sa'y-ı ehl-i himmetden

2. Huṣūl-i makṣad ancaḳ sevḳ-i taḳdīr-i ezeldendir

3. Hasīb ü zì-nesebden ādeme aṣlā żarar gelmez

4. Ne kemlik kim zuhūr eyler kerde mübtezeldendir

5. İrāde ḳıldığı şey'iñ ibdār esbāb-ı āmāde

6. Vuḳūāt-ı cihān cümle Hudā-yı lem-yezeldendir

\section{Ve-lehū}

1. Dīde eñ sevdā-fezā bir șūretiñ hayrānıdır

2. Sīne eñ şiddetli bir sevdānıñ āteş-dānıdır

3. Hüzn-i hicrānıñla mātem-zār gördüm 'ālemi

4. Şimdi her șaḥrā baña bir Kerbelā meydānıdır 


\section{Vel-lehū}

1. Cihānda nām-dār oldur ki bāḳi ḳalsun āsāâr

2. Çıkarsın da zamānında kurırı bir ad neylersin

3. CCekmiş āb u tābı dönmüs etrāfi hazān-dāra

4. İüp bu köhne yerde țarḥ-ı nev-bünyād neylersin

\section{Vel-lehū}

1. Su safvet kim bu gice oldı peydā Tunca nehrinde

2. 'Aceb mis_li görülmüş mi cihānñ bunca nehrinde

3. Bütün meşhūd olan ās_ār-ı luṭf-ı pādişāhīdir

4. Hudā a'dāsını itsün müdemmer dest-i kahrında

\section{Ve-lehū}

1. Mündericdir elem ‘ālemde vü cāh-ı cāhilde

2. 'Ālem-i bī-elem ü cāhil-i bī-cāh olmaz

3. Münderic oldıġıçün nāmları zarfında

4. 'Ālem-i bī-elem ü cāhil-i bì-cāh olmaz

\section{Ve-lehū}

1. Bir serçeyi sahin eline virdi mukadder

2. Şahine didi serçe eyā bāz-ı hümā-per

3. 'Afv eylemeyüp de beni ekle țama' itseñ

4. Bir fāide itmez saña bu cism-i muhakkar

\section{Matla'}

Geldi geçti gördigim demler bütün rü’yā gibi

'Ālemiñ hāli degil mi ȟāa yā hülyā gibi

\section{Beyt}

Mekādir-i āşinādan añla kadr-i ḳadr-mendān Olur ke-mezbehā cevher yed-i nādāna düşdükce

Cevāhir ḳıymetin cevher-şināsı añlar mes_eldir bu Olur ke-mezbehā her şey yed-i nādāna düşdükce

Mațla

Ben de bilmem ki ne hāa oldı baña

'Ālemiñ hāli hāyāl oldı baña

\section{Beyt}

Fāîlātün Fāílātün Fāîlātün Fāíilün

Gark olurdum cūy-ı eske āhım imdād itmese

Olmasa eşkim yanardım āteş-i āhımla ben

\section{Kit'a}

1. Gül alan hārına tayanmalıdır

2. Çünki 'ālemde yoḳ gül-i bì-hââr

3. Görmek içün cemāl-i dil-dārı

4. Çekilür bār-1 minnet-i ag̀yār

\section{Nazm}

1. Benim yokdur efendi irtikābım Anıñçündr ki yokdur ıżțrābım

2. O kesī kim mürtekibdir mużtaribdir Ṭutalım bir ḳapuya müntesibdir

3. Kapular dā’imā olmaz güşāde Getür geçmişleri bir kere yāda

4. Ḳla Ḥaḳk cümleyi ḥıf̣ u himāyet Müyesser ide șıdk u istikāmet

$18 b$

\section{Nazm}

1. Āzerde hāạtır eyleme ahbābıñı șaḳın
Düşmenleriñce bāiss_olur ittifāḳa

2. Ba‘żı sivilci șoñra büyük bir çıban olur Ednā şerer sebebdir ol iḥtirāḳa

3. Göñlüm sever seni güzelim gözlerim arar Kimdir taḥammül eyleye yāriñ firāḳına

4. Üftāde-gānı terkle ag̉yāra olma yār Baḳma rakīib-i fitne-i fettānı̃ nifāḳına

5. Gāhī zuhūur ider küçük işden büyük belā Her kārıñ ihtiyāțla baḳ iştikāḳına

1304 Tārihinde Nisān-ı Fürūg̀-Efșān İmtiyāz-ı İhsān Buyurulduḳda Kendüsi Hațț-ı Destiyle Bir Telg̈rāf Zarfi Üzerine Tesvīd Etmiş Olduğu Ebyāndır Ki ‘Aynen Buraya Naḳl Edildi.

1. Şehin-şāh-ı zamān 'Abdü'l-Hamīd huān-ı kerem-fermā Cihānı eyledi ma'mūr u ābād 'adl ü dadıla

2. Çerāg itdi nişān-ı imtiyāzile o destūrı

3. Cenāb-ı Ahmed 'İzzet müşīr-i müşterī-tal'at Cihāna virdi şöhret yine ‘izz ü şān ü adıla

4. Nişān-ı imtiyāz aldı o düstūr-ı hümā-sāye İrişdi her diyāra müjdesi kuş̧uñ ḳanadıyla

5. O gün kim oldı ta'likk-i nișān ol zāat-ı zì-şān Edirne țoldı ser-tā-ser mesrūr u şevk u şādile

6. O şeb kim eyledi vușlat-ı nişān ma'dilet-efşān Ṭonandı memleket esvāḳ u bāzārñ̃ güşādıyla

7. Atıldı sū-be-sū nice fişseng ü top ra‘dā-vāz Șanur indi yere encüm bakan șem’ ü kanādīle

8. Sanurdı gökden encüm indi kıldı ‘ālemi tenvī Baḳanlar ol şeb īḳād olunan şem‘ ü ḳanādīle

19a

TEVĀRĪH

Tārīh-i Rütbe

Fāilātün Fāílātün Fāillātün Fāílün

1. S Sadr-i mülk-ārā Reşīd Paşa-yı ‘ālī-himmetiñ Ser-be-ser oldı zamānında cihān āsūde-hāl

2. Nā’il-i āmāl-i mā-fìll-bāl olup ehl-i temennā Buldı revnaḳ sāye-i luṭfunda erbāb-ı kemāl

3. Zāāını talțîf içün maḩūmını itdi çerāg Rütbesin terfíle șāhinșeh-i deryā-nevāl

4. Rütbe-i ūlānıñ oldı șınıf-ı s_ānīsi ile Kevkeb-i ümīdi ol mīrīn-i rehīn-i işti‘āl

5. Eylesün ol șadr-i ‘āli-kadri mesrūru'l-fu'ād Gün-be-gün böyle meserretle Rabb-i lā-yezāl

6. Bir du‘ādır maksad ancak imtidād-ı 'ömrine Yohssa baḥs_i vașfinda țākat 'adīmü'l-iḥtimāl

7. Kande kudret kim idem īfā-yı vașf-ı devletin Gördi kim ihsānınıñ şükrin edā emr-i muhāl 
8. Böyle tārīh-i mücevher deste 'İzzet bir düşer Rütbesin ‘ayn eyleye mīr-i celāle żīll-celāl (1258)

\section{Tārīh-i Tebrīk-i Sāl-ı Cedīd} Mefāîlün Mefāîlün Mefāîlün Mefāîlün

1. Serīr-i salțanatda pādişāhım niçe yüz yıllar Saña itsün Cenāb-ı Ḥayy u Mennān 'ömr-i Nūḥ iḥsān

2. Hudāvendā sen ol huākāan-ı 'ālemsin ki dergāhıñ Melāz̄-ı bī-kesāndır ḳıble-gāh-ı fırḳa-i şāhān

3. Zülāl-i feyż-i luṭuñ nār-ı nīrānı ider ițfā Semūm-ı ḳahrıñ eyler murğ-zār-ı düşmeni nīrān

4. 'Umūmen dāhnil-i bāg̀̀-ı ițāaat oldı țāgīler Meger kim ba‘d-ezin țağlarda enhār ile țug̀yān

5. Seniñ fermānıña maḥkūm u münḳād olmayan eşhāṣı 'Aceb olmaz mı şer'an münkir-i ḳur'ānla seyyān

6. Cihān țurduḳca țursun taḩt-i 'ālī baḩt-i şevketde Ser-ā-ser ‘ālemi żabț eylesün mānend-i Kürdistān

7. Du'ā-yı ḩayrile 'İzzet didim cevher gibi tārīh Hezār ems_āl sāl-i nevle olsun şāhımız şādān (1264)

Tārīhn-i Fetḥ-i Sivastopol

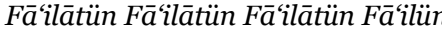

1. Hażret-i ‘Abdü'l-Mecīd ḩānı Hudā manșūr idüp Feth olundı harīb-i tìg-i kahrla Sivastopol

2. Virdi Haḳk bu nușreti ol pādișāh-ı ‘āleme Ṭoldı āvāz-ı beşāretile bu gün İslāmbol

3. Moskol bunca metānet virdigi tersanesi Bir varışda itdi dest-i żabț u teshīre duhūl

4. Seyr idince leşkeriñ berren u bạ̣ren cümlesin Dehșetden şaşdı kaldı Rusya hor u hazūl

5. Çok mıdır bu havfla teslīm iderse mülkini Cān atup ancaḳ reh-i eyne'l-meferre buldı yol

6. Er șanurken kendüsin dirlikden itdi keff-i yed Gördi ḥālin ḳıldı da‘vā-yı şecā‘atden nükūl

7. Karşu țurmak evc-i devlet-i żī-sațvete İște böyle terk-i mülk ü kişver eyler bol bol

8. Söyledim ‘'̇zzet meserretle iki tārīhn-i tām Her biri olsa sezā āvize-i gūş-1 ḳabūl

9. Seyf ile ḳahran alındı sāḥil-i Sivastopol (1271) Seyf-i zecrle alındı kal'a-i Sivastopol (1271)

\section{Tārīhn-i Dīger}

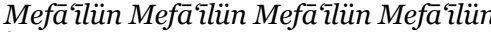

1. İşitdim ḳal'a-i Sivastopol'un feth ü teshīin Mücevher iki tārīhn-i dilārā eyledim inşā

2. S Safā-bahșā olur bu müjde-i ra'nā nüh āfākạa (1271) Șafā virdi bütün işrāḳa işbu müjde-i ‘ulyā (1271)

\section{Rūm İli Demir Yolu'nun Resm-i Güşādına} Tārīhndir

Kayd eyledim Edirne'de tārīhin 'İzzetā

Geldi şemendüfer açılup rāh-ı Rūm İli (1289)
Edirne Piyāde Ḳış̧lasının Ta'mīri Tārīhidir Mefāîlün Mefāîiün Mefāîlün Mefâîiün

1. Bu ḳışla yādigārıdır cenāb-ı hāḳān Mahmūū'uñ Binā itmiş idi ecnādına ol maẓhar-ı gufrān

2. Teșādüf eyleyüp nār-ı każā-yı nāgehānīye Cidār u saḳfı olmışdı dil-i 'āşık gibi vīrān

3. Bi-ḥamdülillāh necl-i necīl vāris_-i taḩtı Şehinşāh-ı cihān 'Abdü'l-'Azīz ḩān 'aẓimüu’ş-şān

4. Bu bünyan-ı cesīmi ḳoymayup ḥāl-i ḩarābīde Buyurdı hey'et-i aṣliyede ta'mīrini fermān

5. İdüp mülki gibi ma'mūr ḳıldı 'askerin mesrūr Ola fetḥ ü ẓaferle pür-sürūr ol sāye-i Yezdān

6. Musahhahar eyleyüp fermānına Ḥaḳk rub'-ı meskūnı Ola tah̆tında bākịi tā ki devrān eyleye devrān

7. Mücevher kilkle 'İzzet kulı kayd itdi tārīhin Bu ḳışlaḳ oldı ḩān-ı ‘Abdü'l-Azīz 'ahdinde ābādān (1290)

Edirne Sarāy-ı Hümāyūnı Ta'mīr Edildikde Ṭarafindan Bi’t-Tanẓīm Cihānünnümā Kașrı Kapusuna Yazılan Tārīh

Fāilātün Fāîlātün Fāílātün Fāilün

1. Pādişāhım oldı ta'mīr emr ü fermānı̃ ile

Bu serā-yı dil-güşā bu feraḩ-bahşā binā

2. Gerçi zātıñda müzeyyen idi ammā gel de bak Şimdi başḳa țarz u revnak eyledi peydā binā

3. Görmemiş mānendini çeşm-i cihān dirsem be-cā Tā olalıdan nüh-țabāk kubbe-i haḍā binā

4. Āl-i Os_mānıñ ḳıyām-ı haşre dek te'yīd eyleye Eyleye ma'mūre-i şevketlerin Mevlā binā

5. 'İzzetā cevherle nakṣ it țāḳına tārīhini Kaṣr-ı ceddin itdi şāhenşāh bālā cā binā (1290)

Tārīh-i Cülūs-ı Hümāyūn-ı Meymenet-makrūn

1. 'Abdü'l-Hamīd hāan eyledi tahtt-ı hümāyūna cülūs 'İzz ü celāli ‘aşkıına Rabb-i hamīd itsün sa'īd

2. Ol şāh manșūru'l-livā bulsun serīinde bekāā Olsun mu'īni dā’imā Huallāḳ-ı zü̉'l-'arşi'l-mecīd

3. Devr eyledikce āsumān olduḳca nīrān Envār-ı 'adlinde cihān olsun ser-a-ser

4. Kadr eyleye her şāmını 'īd eyleye eyyāmını Āmāde ḳılsun kāmını luṭf-i hudāvend-i vahịid

5. Olsun ilā-yevmi'l-ḳıyām emri mețā'-1 hāṣṣ u 'ām Şehler ola emrine rām ecnādına a'dā 'ubeyd

6. Hakk 'ömrini müzdād ide emlākini ābād ide A’dāsını berbād ide Mevlā ilā-yevmi’l-va‘īid

7. Ol ẓll-i Rabbü’l-‘ālemīn ol cānişīn-ı fahr-ı dīn Olsun serīrinde mekīn șevket ile 'ahd-i medīd

8. 'İzzet kulı tārīhnini s_ebt eyledi levh-i dile Oldı zamān sa‘dile sulțān hyān-ı ‘Abdü’l-Ḥamīd (1292) 
Tārīhn-i Tevcīh-i Ṣadāret-i 'Uẓmā Berā-yı Ṣafvet Paşa

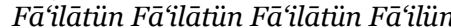

1. Āṣafã virdi saña mührini şāh-ı ‘ālem Eyledi zâatıña mesned-i șadrı a'lā

2. Muntaẓırdı saña çokdan berü ol māh-ı celīl Oldı teşrīf-i ḳudūmüñle mübāhāt efzā

3. Șaḳlamış ḥikmet-i maḩǐsi meger bugün içün Ki ide muhỵīi devlet seni Ḥayy ü Dānā

4. 'Ālemi itmişidi seyl-i havādīs_-i tīre Oldı tedbīr-i mușībiñ aña șafvet-bahşāā

5. Mihr ü meh parladı ‘'̇zzet bu mücevher tārīh Virdi fer șadra celālet ile Șafvet Paşa (1295)

\section{Tārīh-i Sāl}

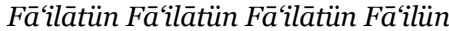

1. Pādişāhım sāl-i ferah-fāliñi sa'y eyleyüp Mebde'-i feyż-i ḳılup cenāb-ı kibriyā

2. Pādişāhım saña her 'asīr olur yesīr Eyler esbābın müheyyā ḩāliḳ-i 'arż u semā

3. Taht-1 'ālī-bahta teşrīiñnde mülkü ü millete Her țarafdan düşmen itmişdi hücūm u i'tidā

4. Şeş cihetden olmadı bir devlete bu iḳtihāām Gerçi vāḳi'dir iki devlet meyānında veḡā

5. Çekdiñ İskender gibi her sūya bir sedd-i sedīd Keyd-i Ye'cūc-i sitemden 'ālemi ḳıldıñ rehā

6. Sīne gerdiñ ḳarşu țurduñ bunca yl āfete Hıfz-ı dīn ü devlet içün rāhatı kıldıñ fedā

7. 'Asrı yesr ü kesri kașr eyler te'āḳub Böyle sebḳat itdi a'ṣār-ı mülūk u enbiyā

8. Zāàt-ı pāk-i faḩr-ı kevneyne müyesser eyledi Fetḥ-i Bațhāyı Ḥudeybiye 'akịibinde Huudā

9. Bād-ı nuṣretle güşād olsun livā-yı devletiñ Ola her 'azmiñde tevfik-i İlāhī reh-nümā

10. Bunca a'dāya tekāaüll kanğı șāhı̃ kārıdır Gelsün 'arẓ itsün tevārīhn-āşināyāne

11. Haḳk te‘ālā ‘ömr ü ikbāliñ ferāvān eylesün Bu du'āyı vird ider ‘'̇zzet ḳuluñ șubh u mesā

12. Oldı bu tārīhnde ẓāhir işāretmiş saña Beyża-i tụgrāda nakș-i el-muzaffer dāimmā

\section{Tārīh-i Diger}

Fāilātün Fã ílātün Fāîlātün Fāiilün

1. Yazdı menşūr teceddüd-i sāle münşī-i ezel Ḳıldı țug̉rā-yı hilāl n'ola pür-zīb ü behā

2. Hükmini meymūn u mes'ūd eyleyüp Rabbü’l-enām Bā‘is_-i feyż ü server itsün be-cāh-ı enbiyā

8 Al-i İmran/155. "İki topluluğun karșılaştı̆̆ gün, içinizden yüz çevirip kaçanları, şeytan ancak yaptıkları bazı hatalardan dolayı yoldan kaydırmak istemişti.
3. Nice böyle sāl-i sa'de irişüp şāh-ı cihān

Taht-ı ‘ālī-bahtt-ı şevketde ola fermān-revā

4. Günleri eyyām-1 $\quad$ īd u yılları olsun sa‘īd 'Ömr ü iḳbālin mezīd itsün cenāb-ı kibriyā

5. Anı manșūr ide fahrü’l-mürselīni bedrde Gāālib-i yevme’l-teḳā-l-cem‘ān ${ }^{8}$ iden bārī Hudā

6. Bād-ı nușretle güşād olsun livā-yı devleti Ola her ‘azminde tevfike-i İlāhī reh-nümā

7. Sāl-i nev tārīhini eyler iken fikr ü hesāb Vāṣıl oldı sem‘a tebșīr ile 'İzzet bu nidā

8. Hażret-i 'Abdü'l-Hamīd hāna olur tārīh-i sāl Meymenet-bahş̧ā-yı tuğrā el-muzaffer dā'imā (1298)

\section{Tārīhn-i Tevcīh-i Ṣadāret-i 'Uzmōā Sa'īd Paşa} Fāilātün Fāílātün Fāíiün

1. Mühr alup hażret-i Saīd Paşa

Kıldı cāh-ı ṣadāreti ihyā

2. Mā-bihi'l-fahr hey'et-i devlet Sadr-i Āsaf nazīr-i mülk-ārā

3. Aña şāyeste șadr-i a'zamlık Aña lāylk o mesned-i ‘ulyā

4. Bu meserretle 'an-șamìmi'l-ḳalb 'İzzetā eyle ref'-i dest-i du'ā

5. Şāh-ı devrāna șadr-ı a'ẓamına Dest-gìr ü mu'īn ola Mevlā

6. Cevherīn harfle olur tārīh Luṭ̂-ı pāk ṣadāret-i 'uẓmā (13oo)

\section{Tārīh-i Sāl}

Fāilātün Fāîlātün Fāîlātün Fāíiün

1. Sen serīr-i salțanatda pādişāhım çok yaşa Birbirin itsün te āḳub sāl-i ferah-făl-i nev

2. Şād ola kalb-i hümāyūnuñ sürūr u şevḳile Eyleye her dem tevcīh zātıña iḳbāl-i nev

3. İhtizār itsün livā-yı şevketiñ iclālile Sū-be-sū olsun müyesser nașr-ı ‘ālü'l-'āl-i nev

4. Eylesün fermān-revā-yı dīn ü dünyā Haḳk seni Böyledir emniyye-i dīrīne vü āmāl-i nev

5. Bu du‘āyı zikr ile ‘'̇zzet kuluñ tebrīk ider Bī-'idād emsāline sāl-i nev olsun dāll-i nev

6. Levha cevherle murașșa yazdı tārīhin ḳalem Bā‘is_-i fevz ola hān-ı ‘Abdü'l-Hamīd’e sāl-i nev (1301)

\section{Tārīh-i Haste-hāne-i Beledī}

Mefāîlün Mefāîlün Mefāî̉ün Mefẫilün

1. Hudā-vend-i mu'azzamam 'Abdü'l-Hamīd hāndır

Şeh-i şāhān 'ālem pādișāh-ı pādişāh-ı ecdād

2. Hükümdār-ı hükm-fermā kerem-kār u kerem-bahşāā

Ama yine de Allah onları affetti. Kuşkusuz Allah çok bağışlayandır, halīmdir". 
Cihān-dār u cihān-ārā cihān-bān u cihān-ābād

3. Anın hükmünde ma'mūr olmadık bir yer mi kalmışdır ‘İmāret-yāb olan ās_ārı olmaz kābil-i ta‘dād

4. Bu huaste-hāāneyi nār-1 kạażā nāgāh idüp iḥrāk Remādiñ rūzgār rūzgār itmiş idi berbād

5. Olunca vāṣıl sem'-ger-i menba'-ı hümāyūnı Bināsın eyledi fermān o şāh-ı merḥamet-mu'tād

6. Yapıldı öyle bir resm-i ferah-efzā kim söyler Harīr-i mıșra'ayn-ı bābı bīmārāna șịhhat bād

7. Serīr-i saltanatda zātını Hakk eyleyüp dā’im İde eyyām-ı ömr ü şevket ü iclālini müzdād

8. Becā vālī-i belde bendesi ‘'̇zzet bu bir beytiñ Ḥurūf-ı sādesinden eylese tārīhnini inşād

9. SŞifā bulsun giren ma'lūl u merżā luṭf-ı bārile Bu haste-hāneyi 'Abdü’l-Hamīd hān kıldı nev-bünyād (1301)

\section{Edirne’de Piyāde Ḳışlası Cāmi'-i Şerīfiniñ Ta'mīri} Tārīh

Mefāîlün Mefāîlün Fe ūlün

1. Şeref-bahşā-yı evreng-i hilāfet Mu'izz-i salțanat ‘Abdü’l-Ḥamīd hnān

2. Emīru'l-mü'minīn hāmī-i ümmet Melāż u muḳtedā-yı ehl-i īmān

3. 'Uluvv-i himmeti iḥyā-yı millet Şi‘ārı neșr-i berr ü 'adl ü ihsān

4. Harāb olmuş hezār ās_ārı yapdı Nice hayr-ı cedīd oldı nümāyān

5. $\quad$ Derūn-ı ḳışlada bu cāmíìde Yapup Mahmūd hān olmıșdı vīrān

6. O hayr-i pāk- pür-envārı itdi Mükemmel vechile ta'mīre fermān

7. Hitāma oldı vāṣıl emr-i ta'mīr Mis_āl-i cennet itdi kesb-i 'imrān

8. O sultān-1 'azīmü’ș-şānñ ‘'̇zzet İde eyyām-ı ‘ömrin Ḥakk ferāvān

9. Ola Rabbānī mansūr u muzaffer Be-fahri'l-enbiyā vü beyt-i Raḥmān

10. Bu tārīhim oḳunsun yād olunsun Du‘ā-yı hayr şāhenșāh-ı devrān

11. Yapıldı cāmi'-i ceddi cedīden İrāde eyleyüp 'Abdü’l-Ḥamīd ḩān (1301)

Tārīhn-i Sāl

Müjde șeh-i ‘āleme bu yıla tārīhdir

Āyet-i nașrun minellāh ve fethun karīb ${ }^{9}$ (1302)

$9 \quad$ Saff/13. "Seveceğiniz başka bir șey daha var: Allah'tan yardım ve yakın bir fetih. (Ey Muhammed!) Müminleri müjdele".

\section{Dīger Tārīh}

1. Bā-'avn-i Rabb-i lā-yezāl itdi teceddüd-i māh u sāl Şāh-ı cihāna sāl-i hạal yümn ü sa‘ādet dāllidir

2. Ems āl-i sāl-i nevle șād itsün anı Rabb-i ‘ibād ‘Așrı̃̃ o șāhib-i ‘adl ü dād hākān-ı zü’l-celālidir

3. Buldı hilāfet mesnedi zāâtıyla 'izz ü sermedī İcrā-yı șer'-i Ahmedī akșā-yı mā-fi-l-bālidir

4. Bak ol veliyyü'n-ni'mete virdi terakkī millete Ḥaḳkıñ bu d in ü devlete iḥsān-ı 'ālü’l-'ālidir

5. Z̄āt-ı hümāyunuñ Hudā İslāma ḳılmış muḳtedā Rahm u kerem cūd u 'ațā hep ol șehiñ ef'ālidir

6. Ta'mīm-i 'adl ü merḥamet neşr-i 'ulūm ü mağfiret İ’mār-ı mülk ü memleket eñ makdem āmālidir

7. Yâ Rabb o sultạn cihān taḩtında olsun kāmurān Tā mihr ü meh-i āsumān yek-digerini tālīdir

8. Bu mıșra'ıdır 'İzzet'iñ tārīhini 'aṣr u müddetiñ Hakk ide es‘ad hicretiñ biñ üç yüz iki sālidir (1302)

\section{Tārīh-i Dīger}

Fāílātün Fāílātün Fāîlātün Fāílün

1. Virdi dünyāya şeref sāl-i hümāyūn fāl-ı nev Sa‘d ide ḥaḳk-1 şāhenşāhīde Rabb-i kibriyā

2. Ol șāhenșāh-ı cihan-ārā ki kıldı 'ālemi Zulmet-i zuulm ü ta'addī vü cehāletden rehā

3. Ol ḩudāvend-i himem-fermā ki halḳ-ı mülkini Eyledi ‘ilm ü me‘ārifle rehīn-i irtikā

4. Tā ebede ylllar teceddüd göstere aylar hilā Taht-ı ‘āli-bahtt-ı şevketde ola fermān-revā

5. Her güni bir māh her bir māhı da șad-sāl olup Mihr-i ‘adl ü re’feti dünyāyı ḳılsun pür-żiyā

6. Bu iki tārīhn -i cevher-dārı taḳdīm eyleyüp Eyledi ‘'̇zzet kulı tebrīk ü tes`īdi edā

7. Sa'd ide 'Abdü’l-Hamīd hāna yeñi sāli Hudā (1302) Eyleye her sāli sa'd 'Abdü’l-Ḥamīd ḩāna Ḩudā (1302)

\section{Tārīh-i Diger}

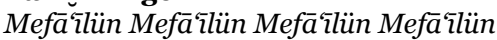

Kuluñ 'İzzet ider bu mısra'-ı tārīh ile tebrīk

Şehenşāhā saña bu sāl-i sa‘d-i nev-mübārek bād (1302)

\section{Sarāc-Hูāne Köprüsünüñ Tecdīdine Tārīhudir} Fāilātün Fāílātün Fāîlātün Fāíiün

1. Ber-ḳarār eyleye tahtında şeh-i devrānı ‘Ömr ü ikbāl-i mü’ebbedle Hudāvend-i mecīd

2. Mülkünüñ her cihetini kesb-i 'imāre itdi Köhne bünyān-ı cihān oldı zamānında cedīd

3. Kaț iderdi rehi Tunca feyżān itdikce Ḳıldı ol bahr-ı kerem işte bu cisri taḥ̂̄id 
4. Yapdırup yanına bir de ḳarag̉ol dāiriresi İtdi āsāyiş-i ibnā-ı sebīli te’yīd

5. Yaḳışur țāḳına tārīhn̆-i mücevher-i 'İzzet Yapdı bu dā’ireyi hazażet-i Sulțān Ḥamīd (1304)

\section{Tārīh-i Cisr}

1. Dārā-yı gerdūn-iḥtişām ḩāḳān-ı İskender-i huadm Dād-āver-i fārūḳ-ı cāh şāh-ı cihān Sulțān Hamīd

2. İ'mār-ı mülk ü devlete șarf eyleyüp sa‘ātini Ḳllmaḳda el-ḥaḳḳ gün-be-gün sükkān-ı mülki müstefid

3. Ez-cümle bu deryā-mis_āl nehri mürūr itmek muhāl İște şeh-i șāhib-i kemāl yapdı aña cisr-i cedīd

4. Bünyād iderken mu'biri yād eyledi ol serveri Şehzāde-i Ḥayder feri Gāāī Süleymān-ı şehīd

5. Yapdırdı cisri şānına biñ hayr oḳutdı cānına Hayrāt-ı şehiñ ihsānına oldı hep ervāh sa‘īd

6. Tā kim semāda kehkeşān tā yerde seyf-i cān-sitān Olduḳca perrān u devān şāhiñ ola ömri mezīd

7. 'İzzet getür bir pür-güher mıșra'la yaz tārīh-i ter Ġāzī Süleymān cisrine ḳurdı binā 'Abdü'l-Ḥamīd (1305)

Tārīhn-i Diger

Fāilātün Fã̄ilātün Fāîlün

1. Emr idüp hażret-i Sulțān Ḥamīd Ḳldı bu cisr-i cesīmi inşā

2. Eyledi ecrini ihdā ola şād Rūḥ-ı şehzāde Süleymān Paşa

3. Bu nehrden güzer olmuşdı mühāā Kaplayup deştī mis_āl-i deryā

4. İ̀tdi bu cisrle te'mīn-i țarìk O şehenşāh-1 'adālet-fermā

5. İdeler her geçeb ebnā-ı sebīl Ḥażret-i bānī-i żīşāna du’ā

6. Kụla tahtında mü'ebbed anı Haḳk Tā ki bāḳi ola nüh-țāḳ-ı semā

7. Emr-i fermān-ı Hümāyūn ‘'̇zzet Oldı bu beytle tārīh binā

8. Yād ola adı bunuñ dünyāda Cisr-i şāhzāde Süleymān Paşa (1305)

Tārīhn-i İnşā-1 Ḩānkāh-ı Kādirī

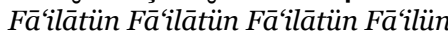

1. K Kıldı inșā hānkāh-ı Seyyid 'Abdü'l-Kādirī Ḥażret-i ‘Abdü'l-Hamīd Hูān ibn-i hāàn 'Abdü'l-Mecīd

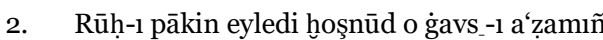
Ol vekīl-ı faḩr-ı ‘ālem sāye-i Rabb-i vahịid

3. Tā ki feyż-efşān ola gül-bāng-ı tevhīid-i Hudā Zīb-i evreng-i hilāfet olsun ol şāh-ı ferīd

4. Pīr ü bernā ezber itsün bu du'āyı ' '̇zzetā Hakk Te ālā eyleye ‘ömr-i hümāyunı mezīd
5. Sālikāna müjde bu tārīhn-i mücevher-dār ile Yapdı dergāhı cedīden ḥażret-i sulțān Hamīd (1305)

\section{Sezāyī Dergāhınıñ Ta'mīri Tārīhi}

Mefāîlün Mefāîlün Mefāîiün Mefāî̀ün

1. Zahīir ola hāā-1 'Abdü'l-Hamīd'iñ evliyāullāh

Kim oldur hāmī-i dīn-i mübīn ü millet-i beyżā

2. 'Adālet ü merḥamet huș zāāt-ı hümāyūnı Huilāfet ü salțanat anıñ ile buldı şeref-ḥakkāā

3. Ne ḩașlet kim şehenşāhāna lāzım cümlesin cāmi Ne kim şāyeste-i şān-ı hükūmetdir ider icrā

4. 'İbādullāhı sevḳ itdi țarīḳ-i Haḳk u 'irfānı Cevāmi'le tekāya vü mekātib eyleyüp inşā

5. Sezāyī-i Velī’niñ hānkāhında idüp ta‘mīr Bu huayrı dahi ihyāya muvaffaḳ eyledi Mevlā

6. Sezādır levḥa naḳs itse ḳalem tārīhini ‘'̇zzet Sezāyī dergehin sulțān Ḥamīd ḩān eyledi ihyā (1305)

Edirne Çeşmeleri Mecrā-yı Ḳadīmine 'İlāve Kılınan Șuyuñ Tārīhidir

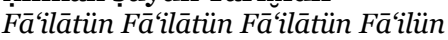

1. Eyledi icrā Edirne sehrine āb-ı hayāt Pādişāh ḥażret-i rehber sāye-i Rabb-i vahīd

2. Yazdı 'İzzet bendesi tārīhn-i cevher-dārını Yapdı bu mecrā-yı mā’ı hażret-i sulțān Hamīd (1307)

Ṭırnovacık Cāmi'-i Șerīfine Tārīhndir Fāílātün Fā'ilātün Fā'ilātün Fā'ilün

1. Eyledi bu cāmi'ini şāhenşeh-ı 'ālem binā Kim odur bünyān-ı hakk u 'adl ü dādıñ vāżı'ı

2. Ol emīru'l-mü’minīn ü muktedā-yı müslimīn Dā’imā itmekde icrā hü̈k-i şer'-i şāriłi

3. Ref'-i dū-dest-i tażarru' eyledim ihllāṣile Șıdkile āmīn-h̆`ān olsun du‘āmıñ sāmi`i

4. H Hayrını idüp ḳabūl ol pādişāh-ı a'ẓamıñ Ṭūl-i ‘ömr iḥsān ide bu kā’inātıñ șāni‘i

5. Serteser āfāka fer virsün şükūh u şevketi Şu'le-bahşs̄a-yı cihān olsun şi'ā'-1 țāli'i

6. Bendesi ‘'́zzet didi tārīhn-i cevher-dārın Hażret-i sulțān Hamīd yapdı bu 'ālī cāmíi (1307)

Piyāde Kışlasınıñ Ġarb Cihetindeki Haste-hāneye Tārīhidir

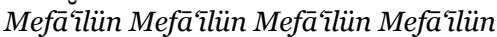

1. Bu bünyād-ı cesīmiñ eyledi inşāsını fermān Nişānındır himmet-i bālā-ter 'Abdü’l-Ḥamīd ḩāna

2. Egerçi oldı inşā ḩaste-ḩāne nāmına ammā İde Haḳk dār-1 șihhat leşker-i ‘Abdü’l-Ḥamīd hāna

3. Bu hisn ü bu reșānetde yapardı seddini ancak Olaydı yāver İskender der-i ‘Abdü'l-Ḥamīd haāna

4. Sa'ādet-yāb 'imrān oldı mülki söyle kim her sū Yeri var reşk iderse kişver-i 'Abdü'l-Ḥamīd ḩāna 
5. H Hudā manșūr idüp innā fetehna $\bar{a}^{10}$ emr ü tebşīi Yazılsun rü’yet-i zer mig̈fer ‘Abdü’l-Hamīd hāna

6. Olup ahbārı gālib sīne-i a'dā vü bed-ȟ `āhı İlāhī ța'ma olsun hancer ‘Abdü'l-Hamīd hāna

7. S S Su beytiñ mühmelinden yazdı 'İzzet bendesi tārīh Ki nakşs olsun bu vālā mü’es_s_er 'Abdü'l-Ḥamīd ḩāna

8. Şifā vü șıhhhat ile her giren bīmār ola dil-şād Yapıldı haste-ḩāne-i 'asker ‘Abdü'l-Ḥamīd ḩāna (1307)

Ṭop Kapu Hāricinde Ḥaḳḳı Paşa cāmi'-i Şerīfi Tārīhi

Fe‘ilātün Fe‘ilātün Fe'lün

(Fāilātün) (Fa'lün)

1. 'Așr-1 sulțān-1 ‘Abdü’l-Hamīd hānīide

Oldı bu cāmi'-i zībā inşā

2. Tā kılındıkca cemā'atle namāz İde ol şāhı mü'ebbed Mevlā

3. Nā’il-i icrā ola ehl-i ḥasenāt İtdiler bu es_er-i ḩayrı binā

4. Beyt-i ātī ile yazdım 'İzzet Bende tārīhini cevher-āsā

5. Ḳ̣ldı Ḥaḳk dāll-i 'alā’l-hূayr-i cezīl Yapdı bu ma'bedi Hakḳı Paşa (1307)

\section{Çoban Ali Efendi Dergāhına Tārīhdir} Fā'ilātün Fā'ilātün Fāillātün Fāilün

1. Hażret-i ‘Abdü’l-Hamīd hnānñ H Hudā-yı lā-yezāl Eyleye eyyām-ı ‘ömr ü şevket ü şānın mezīd

2. Tā esāsından harāb olmuș idi bu hānkāh İtdi ol ḳuṭb-i hilāfet vaż́-ı bünyān-ı cedīd

3. Rūḥ-1 pür-nūr-1 'aliyyü’’r-rā'īìi şād eyledi Kalbini ma'mūr ide anıñda Hallāk-ı vahīd

4. Kalmadı mülkünde bir vīrāne vīrāne dil Cümlesin ta'mīr ü tesrīr itdi ol şāh-ı ferīd

5. ' 'Izzetā imdād-ı çār-akțābıla tāriḩdir Kıldı tecdīden binā bu tekyeyi sulțān Hamīd (1308)

Cisr-i Muștafā Paşa Ḥükūmet Ḳonag̉ına Tārīhndir Mef'ūlü Fāílātü Mefā̄î̀ü Fã íiün

1. Șạhhib-i serīr-i salțanat 'Abdü'l-Hamīd ḩān Bildirdi ‘āleme șeref ü şān-ı devleti

2. Z Zlll-i Hudā halīfe-i fahr-ı rusül ki ol İcrā ider dekāyik hükm-i şer``ati

3. Hakkạā ki s_ālis_ 'ömrin oldı 'adlile Zulmü ü sitemden itdi berī mülk ü milleti

3. Ma'mūr ola memāliki bed-h ${ }^{`}$ āhı ser-nigūn Günden güne füzūnter olup ‘ömr ü şevketi
4. Yapdırdı bu ḳażāda hüūūmet ḳonag̉ını İhḳāḳ içün hukūụḳ-ı șunūf-ı rag̉beti

5. Memdūh olur hemīşe o me'mūr kim ider 'İffetle dīn ü devlet ugurunda hidmeti

6. 'İzet sezā yazılsa bu tārīh bābına Yapdırdı şāh-ı dīn bu dār-ı hükūmeti (1308)

Șaçlı İbrāhīm Efendi Tekyesine Tārīhndir Fāílātün Fā'ilātün Fā'ilātün Fāíiün

1. Hażret-i ‘Abdü'l-Hamīd hān hamīdü'l-haşletiñ 'Ömr ü ikbālin ferāvān eyleye Rabbü’l-enām

2. Kııldı tecdīden binā bu tekyeyi ol pādișāh Olmuș iken nice yıllardır rehīn-i inhidām

3. Feyż-i enfās-ı ricāl-i Celvetiyye andadır Cilve-ger nūr Hüdāȳ’den hidāyet șubḥ u şām

4. Gel devām it zikr ü tevhīde hulūṣ-ı kalbile Olasın tā vāṣıll-ı ser-menzil-i dāru's-selām

5. Bir mübeşşir geldi virdi tārīhin haber Saçlı İbrāhim Efendi dergehi oldı temām (1308)

\section{Tārīh-i Vilādet}

Mefāîlün Mefāîlün Mefāîlün Mefāîlün

1. Bu yıl sulb-i Serverī begden oldı bir veled-i tāli`

İde Hakak țūl-i ‘ömrile kemālāt u șalāh ihsān

2. Çıḳardım kān-ı dilden bir murașșa' mıșra'-ı tārīh Hudā itsün mu'ammer geldi kevne Yūsuf-ı Ken‘ān (1309)

\section{Edirne'de Piyāde Kusşlasına Tārīh}

Mefãîlün Mefāîiün Mefāîiün Mefāîlün

1. S Sehenşāh-1 mu'aẓzam hażret-i 'Abdü'l-Hamīd ḩān kim İder fersūde bünyān-ı cihānı nev-be-nev ābād

2. O rūh-ı cism-i 'ālem nūr-ı dū-çeşm-i benī Ādem Hudāvend-i mufahḩah pādişāh-ı pādişāh ecdād

3. Bu ḳışlaḳ-ı hümāyūnı da tecdīden binā ḳıldı Ki on altı țabur 'asker içinde idile ik ${ }^{\prime} a ̄ d$

4. Bu resm ü bū metānetde bu țarz u bu rașanetde Bu hüsn ü bu cesāmetde binā görmüs mi üstād

5. $\quad$ O rütbe 'askeri hakkında şāmildir ki işfākıı Naẓargāh-ı hümāyūnunda hep mānende-i evlād

6. Memālik-i sāye-i şāhānesinde sū-be-sū ma'mūr Berāyā ẓll-i 'adlinde refāh-ı hâal ile dilşād

7. Münācāt elleriñ aç dergeh-i kāḍ̄i-i hācāta 'Ubūdetile ‘'̇zzet kıl du'ā sen akdem-i evrād

8. Mu'īn ü dest-gīr olsun Hudā her 'azm ü remzinde İdüp eyyām-ı ‘ömr ü şevket ü iclālini müzdād

9. Revādır ḩāme-i cevher ile naḳş olsa tārīhi Bu dil-cū kışlayı kıldı șehenșāh-ı cihān bünyād (1310) 


\section{Sonuç}

Edirne valisi Ahmed İzzet Paşa, 19. yüzyılda yaşamış ve Edirne başta olmak üzere birçok yerde valilik görevlerinde bulunmuş bir devlet adamıdır. 1893'te Edirne'de vefat etmiş ve Üç Şerefeli Camii'nin arkasında Peykler medresesi ile Saatli Medrese'nin arasındaki türbeye defnedilmiştir. Ahmed İzzet Paşa, tedbirli, güçlü, hayır sahibi ve yazmış olduğu şiirleri ile iyi bir şairdir.

Ahmed İzzet Paşa'nın şiir ve gazellerinin olduğu Divançe, Edirneli Ahmed Bâdî Efendi tarafından istinsah edilmiştir ve Edirne Selimie Yazma Eser Kütüphanesi’nde 22 Sel 2311 numarada kayıtlıdır.

Divançe'de miraciye, na't, tazarru, sadrazam Reşîd Paşa'ya kaside, Nâbî ve Hâmî-i Âmidî’nin gazellerine tahmis, 22 gazel ve son bölümde de tarih manzumeleri bulunmaktadır. Tarih manzumeleri, dönemin siyasî ve sosyo-kültürel unsurlarını yansıtması bakımından önemlidir.

$\mathrm{Bu}$ çalışma ile bugüne kadar hakkında çalışma bulunmayan Edirne valisi Ahmed İzzet Paşa Divaneçesi'nin transkripsiyonlu metnini bilim dünyasına sunmuş bulunmaktayız. Bu Divançe’nin Türk edebiyatına katkı sağlayacağı ve bu konuda çalışacaklara fayda sağlayacağı kanaatindeyiz.

\section{Kaynakça}

Adıgüzel, N.; Gündoğdu, R. (2014). Ahmed Bâdî Efendi Riyâa-ı Belde-i Edirne, Edirne: Trakya Üniversitesi.

Çiftçi, Ö. (2017) (e-kitap). Hâtimetü’l-Eş’âr (Fatîn Tezkiresi).

http://ekitap.kulturturizm.gov.tr/Eklenti/55976,fatin-tezkiresi-pdf.pdf?o

Devellioğlu, F. (2006). Osmanlıca-Türkçe Ansiklopedik Lûgat. Ankara: Aydın Kitabevi.

Özkan, E. (2015). "Harput Valisi Hacı Ahmet İzzet Paşa” Fırat Üniversitesi Harput Uygulama ve Araştırma Merkezi Uluslararası Harput’a Değer Katan Şahsiyetler Sempozyumu.

İnal, İ. M. K. (1988). Son Asır Türk Şairleri. İstanbul: Dergâh.

Peremeci, O. N. (2011). Edirne Tarihi. Edirne: Bellek.

Şemseddin Sâmi. (1317). Kâmûs-ı Türkî, Dersaâdet.

Yörür, A.. (2018). "Edirne Valisi Ahmed İzzet Paşa'nın Mi’râciye'si” MECMUA Uluslararası Sosyal Bilimler Dergisi.

Yörür, A. (2019), “Edirne Valisi Ahmed İzzet Paşa’nın Tarih Manzumeleri” Littera Turca Journal Turkish Language and Literature. 